Review

\title{
Therapeutic Cancer Vaccination with Ex Vivo RNA-Transfected Dendritic Cells-An Update
}

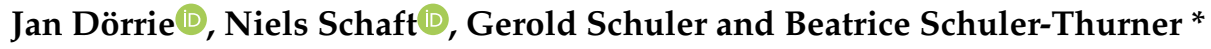 \\ Department of Dermatology, Universitätsklinikum Erlangen, Friedrich-Alexander-Universität \\ Erlangen-Nürnberg, Hartmannstraße 14, 91052 Erlangen, Germany; jan.doerrie@uk-erlangen.de (J.D.); \\ niels.schaft@uk-erlangen.de (N.S.); gerold.schuler@uk-erlangen.de (G.S.) \\ * Correspondence: beatrice.schuler-thurner@uk-erlangen.de; Tel.: +49-9131-853-3724
}

Received: 13 December 2019; Accepted: 18 January 2020; Published: 23 January 2020

\begin{abstract}
Over the last two decades, dendritic cell (DC) vaccination has been studied extensively as active immunotherapy in cancer treatment and has been proven safe in all clinical trials both with respect to short and long-term side effects. For antigen-loading of dendritic cells (DCs) one method is to introduce mRNA coding for the desired antigens. To target the whole antigenic repertoire of a tumor, even the total tumor mRNA of a macrodissected biopsy sample can be used. To date, reports have been published on a total of 781 patients suffering from different tumor entities and HIV-infection, who have been treated with DCs loaded with mRNA. The majority of those were melanoma patients, followed by HIV-infected patients, but leukemias, brain tumors, prostate cancer, renal cell carcinomas, pancreatic cancers and several others have also been treated. Next to antigen-loading, mRNA-electroporation allows a purposeful manipulation of the DCs' phenotype and function to enhance their immunogenicity. In this review, we intend to give a comprehensive summary of what has been published regarding clinical testing of ex vivo generated mRNA-transfected DCs, with respect to safety and risk/benefit evaluations, choice of tumor antigens and RNA-source, and the design of better DCs for vaccination by transfection of mRNA-encoded functional proteins.
\end{abstract}

Keywords: therapeutic vaccination; dendritic cells; RNA; electroporation; clinical trial; immunotherapy

\section{Tumors and the Immune System}

Therapeutic cancer vaccination is a concept for treating tumor patients by immunizing them against their own tumor. As early as 1891, the application of bacterial substances (which we now know to have served as adjuvants) into tumors was executed by William Coley, who achieved a clinical response rate of $10 \%$ in soft tissue sarcoma [1,2]. During the 20th century, chemotherapy and radiation therapy were developed and superseded immunotherapy. The concept of immune surveillance, however, was later resumed and pursued [3,4] (and reviewed by [5,6]). The striking success that was achieved in preventive vaccination against infectious diseases suggested that the immune system could be utilized against malignancies in a similar fashion.

\section{Therapeutic and Preventive Vaccination}

There are, however, crucial differences between a preventive vaccine against an infectious disease and a therapeutic vaccination against an existing cancer. Firstly, the malignant cells arise from the body's own healthy cells-therefore, the immune system's primary function to distinguish self from foreign is circumvented. Secondly, the malignancy has developed in the presence of a functioning immune system and has hence adapted to immune surveillance. Thirdly, most tumors influence the immune system in their favor. Due to these circumstances, the induction of an effective anti-tumor immunity 
resembles that of a selective autoimmunity under arduous conditions. This necessitates the use of a highly immunogenic vaccination strategy, able to break tolerance and overcome immune suppression.

\section{Dendritic Cells as Cancer Vaccine}

The mammalian cell type which is specialized in initiating all adaptive immune responses was described in 1973 by Ralph Steinman and Zanvil Cohn and termed dendritic cells (DCs) [7]. They are considered to be sentinels of the immune system [8,9], and watch over the induction of immune responses and the maintenance of tolerance. They are also considered to be the link between innate and adaptive immunity [10].

The ability of DCs to induce tumor regression in murine models was shown more than two decades ago [11,12]. The first application in human beings was reported in 1996 [13], although the cells used in this study did not constitute highly enriched real DCs according to standards set later on [14], and a first practical protocol for generating human DCs in sufficient numbers from blood monocytes was also published in 1996 [15]. This opened up the possibility of a broader clinical application of DCs, and other encouraging reports soon followed [16,17]. Immune responses induced by the vaccination were later shown to correlate with clinical results, notably if monitored in tissues [18]. Although alternative protocols to generate DCs followed [19-21], the majority of clinical trials used this original protocol to generate monocyte-derived DCs (moDCs) by incubation over 5 to 8 days with GM-CSF and IL-4 [10,15] (see Table 1).

\subsection{Dendritic Cell Maturation}

To become immunogenic, a DC needs to undergo a process termed maturation [22]. This complex program is naturally induced by an exposure of the DC to danger signals [23]. It involves various phenotypic changes, including the up-regulation of co-stimulatory surface markers and the secretion of pro-inflammatory cytokines. The DCs' ability to migrate toward peripheral lymph nodes, where they encounter the naïve T cells, also depends on the DCs' maturation state [24]. It is, therefore, not surprising that maturation is an absolute prerequisite for the immunogenicity of DCs in vivo in humans [24]. Immature DCs were shown to even induce tolerance [25].

In moDCs, the maturation can be triggered with monocyte-conditioned medium [26]. This can be replaced with a cocktail of cytokines consisting of IL-1ß, IL-6, TNF, and PGE 2 [27], termed MCM-mimic (MCMM) [26]. As shown in Table 1, the MCMM cocktail was used in the majority of published clinical trials, but other cocktails, including, e.g., IFN $\gamma$ or TLR agonists, but also TNF $\alpha$ alone or combined with $\mathrm{PGE}_{2}$ only, have been used.

\subsection{Loading Dendritic Cells with Antigen}

The most straightforward way to load DCs with tumor antigen-derived epitopes is the direct pulsing with synthetic peptides, which was shown already in the initial DC trials to induce the corresponding immune responses [17]. This, however, requires the patient to be of an HLA haplotype for which suitable epitopes exist. An alternative is the use of larger parts of the antigen, i.e., long peptides [28] or even full-length proteins, which are then processed and cleaved by the DC's endogenous antigen processing machinery. This results in the generation and presentation of relevant natural epitopes, which are contained in the antigen and fit into the HLA molecules of the DC, and thus also the patient's HLA repertoire. 
Table 1. Antigens and diseases treated with RNA-transfected DCs.

\begin{tabular}{|c|c|c|c|c|c|c|}
\hline RNA Used & Malignancy/Disease & $\begin{array}{c}\text { Patients } \\
\text { Vaccinated }\end{array}$ & Phase & DC Culturing & Maturation & Reference \\
\hline \multirow{9}{*}{ Autologous tumor RNA (aT-RNA) } & Colorectal ca m & 15 & $\mathrm{I}$ & Standard (including FCS) & No & [29] \\
\hline & Colon ca & 1 & 0 & Standard & $\mathrm{TNF} \alpha$ & [30] \\
\hline & Renal cell ca m & 10 & I & Standard & No & [31] \\
\hline & Pediatric brain tumors & 7 & I & Standard & No & [32] \\
\hline & Pediatric neuroblastoma stage IV & 8 & I & Standard & No & [33] \\
\hline & Renal cell ca m, ovarian ca & 11 & ns & Standard & MCMM & [34] \\
\hline & Melanoma stage IV & 6 & I & Standard (Clinimacs) & $\mathrm{TNF} \alpha+\mathrm{PGE}_{2}$ & [35] \\
\hline & Renal cell ca m & 21 & II & Standard & $\mathrm{TNF} \alpha+\mathrm{PGE}_{2}+\mathrm{IFN} \gamma+\mathrm{CD} 40 \mathrm{~L}-\mathrm{mRNA}$ & [36] \\
\hline & Melanoma stage IV & 31 & $\mathrm{I} / \mathrm{II}$ & Standard & MCMM & {$[37]$} \\
\hline aTSC-RNA (tumor stem cells) & Glioblastoma & 7 & $\mathrm{I} / \mathrm{II}$ & Standard (5 days) & MCMM & [38] \\
\hline $\begin{array}{l}\text { Allogeneic tumor RNA (3 human } \\
\text { cancer cell lines) }\end{array}$ & Prostate ca & 19 & $\mathrm{I} / \mathrm{II}$ & Standard & MCMM & [39] \\
\hline $\begin{array}{l}\text { MAGE-A1- MAGE-A3-, MAGE-C2-, } \\
\text { MelanA-, tyrosinase-, and/or } \\
\text { gp100-DC-Lamp mRNA }\end{array}$ & Melanoma stage III and IV & 30 & $I^{*}$ & Standard (6 days) & TriMix or polyIC + CD40L-mRNA & [40] \\
\hline \multirow{3}{*}{$\begin{array}{l}\text { MAGE-A3-, MAGE-C2-, tyrosinase-, } \\
\text { gp100-DC-Lamp mRNA }\end{array}$} & Melanoma stage IIIC and IV & 35 & $I^{*}$ & Standard (6 days) & TriMix- mRNA & [41] \\
\hline & Melanoma stage IIIC and IV & 15 & IB & Standard (6 days) & TriMix-mRNA & [42] \\
\hline & Melanoma stage IIIC and IV & 39 & II & Standard (6 days) & TriMix-mRNA & [43] \\
\hline gp100 or tyrosinase mRNA & Melanoma m stage III & 11 & $\mathrm{I} / \mathrm{II}$ & Standard & $\mathrm{MCM}+\mathrm{TNF} \alpha+\mathrm{PGE}_{2}$ & [44] \\
\hline \multirow{4}{*}{ gp100 and tyrosinase mRNA } & Melanoma stage III and IV & 45 & $\mathrm{I} / \mathrm{II}$ & Standard (5-7 days) & $\mathrm{MCM}+\mathrm{PGE}_{2}+\mathrm{TNF} \alpha$ & [45] \\
\hline & Melanoma stage III and IV & 15 & $\mathrm{I} / \mathrm{II}$ & Standard & TriMix-mRNA & [46] \\
\hline & Melanoma stage III and IV & 28 & $\mathrm{I} / \mathrm{II}$ & Standard & TLR-agonists from conventional vaccines & [47] \\
\hline & Uveal melanoma & 23 & $\mathrm{I} / \mathrm{II}$ & Standard & ns & [48] \\
\hline $\begin{array}{l}\text { MelanA, MAGE-A3, gp100, } \\
\text { and tyrosinase mRNA }\end{array}$ & Melanoma m & 12 & I & Standard (5 days) & MCMM & [49] \\
\hline hTERT, survivin, and p53 mRNA & Advanced melanoma & 22 & I & Standard & ns & {$[50]$} \\
\hline MAGE-A3, survivin, BCMA mRNA & Multiple myeloma stage II/III & 12 & I & Standard & MCMM & [51] \\
\hline MUC1 and survivin mRNA & Renal cell carcinoma & 28 & $\mathrm{I} / \mathrm{II}$ & Standard (4 days) & $\mathrm{TNF} \alpha$ & [52] \\
\hline \multirow{3}{*}{ CEA mRNA } & Pancreatic cancer & 3 & ns & Standard & No & [53] \\
\hline & CEA expressing malignancies & 37 & $\mathrm{I} / \mathrm{II}$ & Standard & No & [54] \\
\hline & Colorectal cancer m & 5 & $\mathrm{I} / \mathrm{II}$ & Standard & MCMM & [55] \\
\hline
\end{tabular}


Table 1. Cont.

\begin{tabular}{|c|c|c|c|c|c|c|}
\hline RNA Used & Malignancy/Disease & $\begin{array}{c}\text { Patients } \\
\text { Vaccinated }\end{array}$ & Phase & DC Culturing & Maturation & Reference \\
\hline PSA mRNA & Prostate cancer $\mathrm{m}$ & 13 & I & Standard & No & {$[56]$} \\
\hline \multirow{2}{*}{ hTERT mRNA, +/- LAMP } & Prostate cancer $\mathrm{m}$ & 20 & I & Standard & MCMM & {$[57]$} \\
\hline & AML & 21 & II & ns & ns & [58] \\
\hline $\begin{array}{l}\text { PSA, PAP, survivin, and hTERT } \\
\text { mRNA }\end{array}$ & Castration-resistant prostate ca & 21 & II & Standard & ns & [59] \\
\hline Folat receptor mRNA & Ovarian cancer $\mathrm{m}$ & 1 & 0 & Standard & MCMM & {$[60]$} \\
\hline \multirow{3}{*}{ WT1 mRNA } & AML & 10 & $\mathrm{I} / \mathrm{II}$ & Standard (6 days) & $\mathrm{TNF} \alpha+\mathrm{PGE}_{2}$ & [61] \\
\hline & Uterine cancer & 6 & $\mathrm{I} / \mathrm{II}$ & Standard (6 days) & $\mathrm{TNF} \alpha+\mathrm{IL} 1 \beta$ & [62] \\
\hline & Ovarian & 2 & $\mathrm{I} / \mathrm{II}$ & Standard (6 days) & $\mathrm{TNF} \alpha+\mathrm{IL} 1 \beta$ & [63] \\
\hline WT1 mRNA +/- DC-Lamp & AML & 20 & II & Standard (6 days) & $\mathrm{TNF} \alpha+\mathrm{PGE}_{2}$ & [64] \\
\hline MUC1 mRNA & Pancreatic cancer & 42 & ns & Standard (6 days) & $\mathrm{TNF} \alpha$ & [65] \\
\hline CMV pp65.LAMP mRNA & Glioblastoma & 12 & I & Standard & MCMM & [66] \\
\hline HSP70 & HCV-related hepatocarcinoma & 12 & I & Standard & $\mathrm{TNF} \alpha$ & [67] \\
\hline \multirow{3}{*}{ CMV pp65 mRNA } & $\begin{array}{l}\text { Hematopoietic stem cell } \\
\text { transplantation }\end{array}$ & 7 & ns & $\begin{array}{l}\text { Standard (6 days } \\
\text { clinimacs) }\end{array}$ & $\mathrm{TNF} \alpha, \mathrm{PGE}_{2}$ & {$[68]$} \\
\hline & Glioblastoma & 11 & $\mathrm{I}$ & Standard from CD34+ & ns & [69] \\
\hline & Glioblastoma & 9 & I & Standard & MCMM & [70] \\
\hline Gag and Nef mRNA & HIV infection & 10 & $\mathrm{I} / \mathrm{II}$ & Standard (5 days) & MCMM & [71] \\
\hline \multirow{2}{*}{ Gag, Vpr, Rev and Nef mRNA } & HIV infection & 10 & $\mathrm{I} / \mathrm{II}$ & Standard & $\mathrm{TNF} \alpha+\mathrm{IFN} \gamma+\mathrm{PGE}_{2}+\mathrm{CD} 40 \mathrm{~L}$ mRNA & [72] \\
\hline & HIV infection & 35 & IIB & Standard & $\mathrm{TNFa}+\mathrm{IFN} \gamma+\mathrm{PGE}_{2}+\mathrm{CD} 40 \mathrm{~L}-\mathrm{mRNA}$ & [73] \\
\hline $\begin{array}{c}\text { Gag-, Tat-, Rev-, and Nef-DC-Lamp } \\
\text { mRNA }\end{array}$ & HIV infection & 17 & I/IIa & Standard (6 days) & MCMM & [74] \\
\hline $\begin{array}{c}\text { Gag- and Tat-Nef-Rev-DC-Lamp } \\
\text { mRNA }\end{array}$ & HIV infection & 6 & $\mathrm{I} / \mathrm{II}$ & Standard (clinimacs) & $\mathrm{TNF} \alpha+\mathrm{PGE}_{2}$ & [75] \\
\hline
\end{tabular}




\subsection{RNA-Transfection of Dendritic Cells}

The easiest way to achieve MHC class I-restricted presentation in this fashion is the intracellular expression of the antigens, and a method considered ideal for clinical application is mRNA transfection [76]. Several forms of RNA transfection have been used by different groups over the past decades, e.g.: passive pulsing of mRNA, i.e., simple co-incubation of mRNA with the DCs, lipid-mediated transfection of mRNA, and mRNA electroporation, i.e., transfer of mRNA molecules through the cell membrane by an electrical pulse (reviewed in [77]), with the latter being used by most groups at present. Figure 1 gives a schematic overview. When mRNA electroporation is performed properly, transfection rates above $90 \%$ are feasible. This physical method requires no additional chemicals, which is beneficial under GMP conditions. Until now, most clinical trials applying mRNA-transfected DCs have used mRNAs encoding defined non-mutated tumor antigens. However, one can also perform sequencing of the tumor and identify mutated neo-antigens, which are considered more immunogenic, but are hampered by the fact that they seem to be rarely presented and constitute less than 1\% of the HLA-ligandome [78-80]. To our knowledge, mRNAs encoding such mutated neo-antigens have only been used as a direct vaccine by injection into the lymph nodes [81], and thus far not in a DC vaccine.

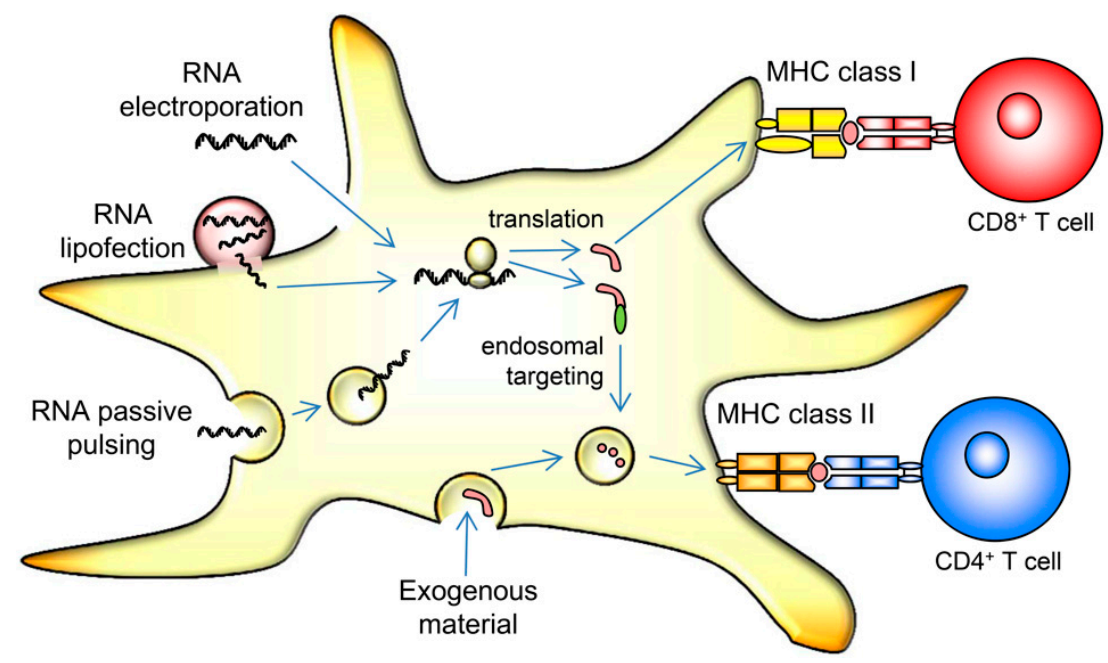

Figure 1. Schematic representation of an mRNA-transfected DC. Endocytosed and phagocytosed material is usually presented in MHC class II to CD4 ${ }^{+}$helper T cells and can be cross-presented in MHC class I only under certain circumstances (not depicted). Proteins from the cytoplasm are, in contrast, primarily presented in MHC class I. mRNA can be introduced into cells by passive pulsing, relying on intrinsic and yet unknown means of uptake. It can be complexed with lipid reagents that mediate entry into the cytoplasm, or it can be transfected by electroporation. By applying a short electric pulse, pores in the cell membrane temporarily open, allowing entry of the RNA molecules. The transferred mRNA is then translated in the cytoplasm, and the encoded antigens are hence presented in a MHC class I context. By encoding signaling and targeting sequences (green) fused to the antigenic protein, this can also be directed towards the endosomal pathway, resulting in efficient MHC class II presentation.

An initial drawback of intracellularly expressed antigens is their limited presentation in MHC class II molecules for recognition by $\mathrm{CD}^{+}$helper $\mathrm{T}$ cells. While more experience was gathered in the field of DC vaccination, the relevance of T-cell-help in anti-tumor responses emerged. CD4 ${ }^{+}$helper T cells were shown to facilitate the generation of memory-type CD8 ${ }^{+} \mathrm{T}$ cells and, hence, this hurdle was overcome by fusing the mRNA-encoded antigens with targeting sequences, which direct the antigen towards the lysosomal compartment, thus mediating MHC class II-restricted presentation in addition to $\mathrm{MHC}$ class I-restricted presentation (Figure 1). Common targeting sequences were derived from lysosomal-associated membrane proteins (LAMP) like LAMP-1 [57] and DC-LAMP [82]. 
An additional merit of mRNA electroporation lies in the possibility of introducing not only antigens, but also functional proteins into the DCs, thus manipulating their phenotype and providing additional activation and maturation signals. The group around Kris Thielemans developed a DC-maturation process completely independent of exogenous cytokines by utilizing a mix of mRNAs encoding CD40L, CD70, and a constitutively active TLR4. This formulation was termed TriMix, and was used in a variety of clinical trials [40-43,46] (reviewed in [83]). Others used cytokine-matured DCs transfected with CD40L [84] to treat renal cell carcinoma [36] or HIV infection [72,73]. We commonly transfected cytokine-matured DC, but recently utilized a constitutively active form of IKKß to improve T-cell [85] and NK-cell activation [86], which will be tested in a phase I clinical trial soon.

\subsection{The Total Tumor RNA Approach}

The use of one or a few defined tumor antigens still limits the possibly induced anti-tumor immunity, and it has been shown that human anti-melanoma immunity is dominated by T-cell responses directed against somatically and individually mutated antigens [87]. Hence, the idea arose to use the entire tumor transcriptome by extraction, and, if needed, PCR-based amplification of tumor mRNA for subsequent electroporation into the DCs.

This allows an individualized treatment exploiting the complete antigenic repertoire of a given tumor, even if possible defined rejection antigens are yet unknown. In this aspect, total tumor mRNA is similar to the use of dead tumor cells but is not restricted by limitations regarding the size of excised tumors, reproducibility and validation. Exploitation of the total antigenic repertoire is considered critical as it targets not only overexpressed antigens but also the mutated proteins including both passenger as well as oncogenic driver mutations $[88,89]$ and the emerging class of non-mutated neoantigens [90].

\section{From the Bench to the Bedside}

The potential clinical benefit of RNA-loaded DC therapy was first demonstrated in mouse tumor models. Mice treated with DCs pulsed with RNA from ovalbumin (OVA)-expressing tumor cells were protected against a challenge with OVA-expressing tumor cells [91]. In the same study, mice in the poorly immunogenic, highly metastatic, B16/F10 (B16) tumor model demonstrated a dramatic reduction in lung metastases in animals treated with DCs pulsed with tumor-derived RNA. Again using the B16 model, a second study showed that treatment with bone marrow-generated DCs, pulsed with either B16 cell extract or B16 total RNA induced specific CTLs against B16 tumor cells [92]. This treatment was able to protect animals from tumor located in the central nervous system (CNS), and led to prolonged survival in mice with tumors placed before initiation of therapy [92].

When this technology was taken from the bench to the bedside (as schematically represented in Figure 2), already the initial clinical trials were promising, demonstrating feasibility and immunogenicity, as well as hints for clinical efficacy. For example, a DC/RNA vaccine was explored in a phase I trial to treat eleven subjects presenting with metastatic RCC [31]. While the primary objectives of this study were safety, feasibility, and immunological assessment, it was noteworthy that tumor-related mortality was unexpectedly low among the 10 evaluable subjects who received the prescribed three administrations. The calculated mean survival following nephrectomy was $19.8 \pm 3.1$ months, although survival interpretation was confounded by the post-study therapies (predominately cytokine) received by most subjects. There were no adverse drug reactions with the exception of five subjects who experienced grade I injection site reactions consisting of inflammatory skin erythema lasting 48-72 h. A polyclonal tumor-specific T-cell response was detected in six subjects evaluable for immune response following DC treatment. Comparable results were observed in a phase I/II trial of melanoma therapy with autologous tumor mRNA $[93,94]$. The published clinical trials using tumor-RNA-transfected DCs are summarized in Tables 1-3. 
Table 2. Clinical efficacy of RNA-based DC trials.

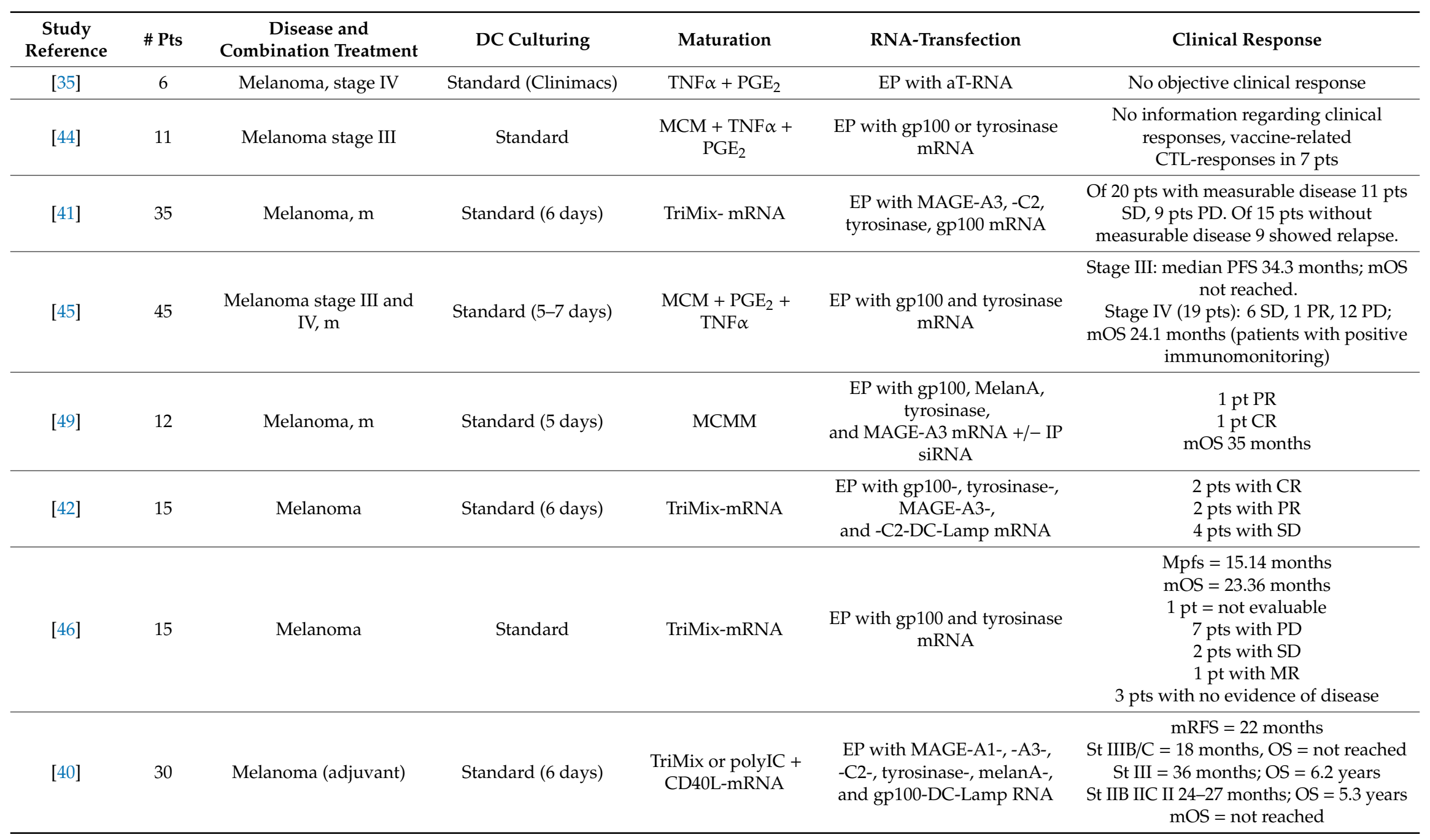


Table 2. Cont

\begin{tabular}{|c|c|c|c|c|c|c|}
\hline $\begin{array}{c}\text { Study } \\
\text { Reference }\end{array}$ & \# Pts & $\begin{array}{c}\text { Disease and } \\
\text { Combination Treatment }\end{array}$ & DC Culturing & Maturation & RNA-Transfection & Clinical Response \\
\hline$[47]$ & 28 & $\begin{array}{c}\text { Melanoma stage III and } \\
\text { IV }\end{array}$ & Standard & $\begin{array}{l}\text { TLR-agonists from } \\
\text { conventional } \\
\text { vaccines }\end{array}$ & $\begin{array}{c}\text { EP with gp100 and tyrosinase } \\
\text { mRNA }\end{array}$ & 4 pts with SD \\
\hline$[37]$ & 31 & Advanced melanoma & Standard & MCMM & EP with aT-RNA & $\begin{array}{l}1 \text { pt with PR } \\
3 \text { pts with SD } \\
\text { OS } 10 \text { months }\end{array}$ \\
\hline$[50]$ & 22 & $\begin{array}{l}\text { Malignant melanoma } \\
\text { Cyclophosphamide }\end{array}$ & Standard & ns & $\begin{array}{c}\text { EP with hTERT, survivin, } \\
\text { p53 mRNA }\end{array}$ & $\begin{array}{l}9 \text { pts with SD } \\
\text { mPFS } 3.1 \text { months } \\
\text { mOS } 10.4 \text { months }\end{array}$ \\
\hline [43] & 39 & $\begin{array}{l}\text { Pretreated advanced } \\
\text { melanoma Ipilimumab }\end{array}$ & Standard (6 days) & TriMix-mRNA & $\begin{array}{c}\text { EP with MAGE-A3-, -C2-, } \\
\text { tyrosinase-, } \\
\text { and gp100-DC-LAMP mRNA }\end{array}$ & $\begin{array}{c}8 \text { pts with CR } \\
7 \text { pts with PR } \\
6 \text { pts with SD } \\
\text { mPFS } 27 \text { weeks } \\
\text { mOS } 59 \text { weeks }\end{array}$ \\
\hline [48] & 23 & Uveal melanoma & Standard & ns & $\begin{array}{c}\text { EP with gp100 and tyrosinase } \\
\text { mRNA }\end{array}$ & $\begin{array}{l}\text { mDFS } 34.5 \text { months } \\
\text { mOS } 51.8 \text { months }\end{array}$ \\
\hline [62] & 2 & Ovarian cancer & Standard (6 days) & $\mathrm{TNF} \alpha+\mathrm{IL} 1 \beta$ & EP with WT1 mRNA & $\begin{array}{l}\text { Patients with ovarian carcinosarcoma } \\
\text { showed OS of } 70 \text { months (vs } \\
15.5 \text { months in historical controls). }\end{array}$ \\
\hline$[63]$ & 6 & Uterine cancer & Standard (6 days) & $\mathrm{TNF} \alpha+\mathrm{IL} 1 \beta$ & EP with WT1 mRNA & $\begin{array}{l}\text { OS of } 10 \text { to } 11 \text { months compared to } \\
2-5 \text { months historical controls }\end{array}$ \\
\hline$[31]$ & 10 & $\begin{array}{l}\text { Renal cell carcinoma, } \\
\text { stage III or IV }\end{array}$ & Standard & No & co-incubation with aT-RNA & 7 pts $\mathrm{SD} /$ slow progression \\
\hline [34] & 11 & $\begin{array}{c}\text { Renal cell cancer, } \\
\text { m (10 pts), ovarial } \\
\text { carcinoma (1pt) Ontak }^{\circledR}\end{array}$ & Standard & MCMM & EP with aT-RNA & $\begin{array}{l}\text { Increase in tumor-specific CTL, } \\
\text { no information on clinical responses }\end{array}$ \\
\hline
\end{tabular}


Table 2. Cont

\begin{tabular}{|c|c|c|c|c|c|c|}
\hline $\begin{array}{c}\text { Study } \\
\text { Reference }\end{array}$ & \# Pts & $\begin{array}{c}\text { Disease and } \\
\text { Combination Treatment }\end{array}$ & DC Culturing & Maturation & RNA-Transfection & Clinical Response \\
\hline$[52]$ & 28 & $\begin{array}{c}\text { Renal cell cancer } \\
\text { cytokine-induced killer } \\
\text { cells }\end{array}$ & Standard (4 days) & $\mathrm{TNF} \alpha$ & $\begin{array}{c}\text { EP with MUC-1 and survivin } \\
\text { mRNA }\end{array}$ & $\begin{array}{c}4 \text { pts with CR: } 2>10 \text { months; } 2> \\
15 \text { months } \\
7 \text { pts with PR (6-21 months) } \\
10 \text { pts with SD (5-21 months) } \\
6 \text { pts with PD/1 death }\end{array}$ \\
\hline [36] & 21 & Renal cell cancer sunitinib & Standard & $\begin{array}{c}\mathrm{TNF} \alpha+\mathrm{PGE}_{2}+ \\
\text { IFN } \gamma+ \\
\text { CD40L-mRNA }\end{array}$ & EP with aT-RNA & $\begin{array}{c}5 \text { pts with PR } \\
8 \text { pts with SD } \\
13 \text { pts with PR + SD } \\
8 \text { pts with PD } \\
\text { Median OS:30.2 months }\end{array}$ \\
\hline$[56]$ & 13 & Prostate cancer, $\mathrm{m}$ & Standard & No & $\begin{array}{c}\text { co-incubation with PSA } \\
\text { mRNA }\end{array}$ & $\begin{array}{l}1 \mathrm{pt} \text { decrease of PSA level, } 5 \text { pts } \\
\text { reduction PSA log slope, } 3 \text { pts transient } \\
\text { elimination of tumor cells in peripheral } \\
\text { blood }\end{array}$ \\
\hline [39] & 19 & $\begin{array}{l}\text { Prostate cancer, androgen } \\
\text { resistant }\end{array}$ & Standard & MCMM & $\begin{array}{l}\text { EP with allogeneic tumor } \\
\text { RNA (3 human cancer cell } \\
\text { lines) }\end{array}$ & $\begin{array}{c}11 \text { pts SD (PSA) } \\
13 \text { pts decreased log slope PSA }\end{array}$ \\
\hline [59] & 21 & $\begin{array}{l}\text { Castration-resistant } \\
\text { prostate cancer docetaxel }\end{array}$ & Standard & ns & $\begin{array}{c}\text { EP with PSA, PAP, survivin, } \\
\text { hTERT mRNA }\end{array}$ & mPFS 5.5 months \\
\hline [32] & 7 & Pediatric brain tumors & Standard & No & co-incubation with aT-RNA & 0 pt CR, 1 pt PR, 2 pts SD \\
\hline [33] & 8 & $\begin{array}{l}\text { Pediatric neuroblastoma } \\
\text { stage IV }\end{array}$ & Standard & No & co-incubation with aT-RNA & No objective clinical response \\
\hline [38] & 7 & Glioblastoma & Standard (5 days) & MCMM & EP with aT-RNA & $\begin{array}{c}\text { Median PFS of } 694 \text { days vs. } 236 \text { days in } \\
\text { historical controls } \\
\text { Median OS of } 759 \text { days vs. } 585 \text { days in } \\
\text { historical controls }\end{array}$ \\
\hline
\end{tabular}


Table 2. Cont.

\begin{tabular}{|c|c|c|c|c|c|c|}
\hline $\begin{array}{c}\text { Study } \\
\text { Reference }\end{array}$ & \# Pts & $\begin{array}{c}\text { Disease and } \\
\text { Combination Treatment }\end{array}$ & DC Culturing & Maturation & RNA-Transfection & Clinical Response \\
\hline$[66]$ & 12 & $\begin{array}{l}\text { Glioblastoma injection } \\
\text { site preconditioned with } \\
\text { tetanus toxoid }\end{array}$ & Standard & MCMM & EP with CMV pp65 mRNA & $\begin{array}{l}\text { mPFS of } 10.8 \text { months; } \\
\text { mOS } 18.5 \text { months }\end{array}$ \\
\hline [69] & 11 & $\begin{array}{l}\text { Glioblastoma } \\
\text { temozolimide DCs mixed } \\
\text { with GM-CSF }\end{array}$ & Standard from CD34+ & ns & EP with CMV pp65 mRNA & $\begin{array}{l}\text { mPFS } 25.3 \text { months } \\
\text { mOS } 41.1 \text { months }\end{array}$ \\
\hline$[70]$ & 9 & $\begin{array}{l}\text { Glioblastoma adoptive } \\
\text { T-cell transfer }\end{array}$ & Standard & MCMM & EP with CMV pp65 mRNA & $\begin{array}{l}\text { increase in polyfunctinal pp65-specific } \\
\text { T cells }\end{array}$ \\
\hline$[53]$ & 3 & $\begin{array}{c}\text { Pancreatic } \\
\text { adenocarcinoma, CEA } \\
\text { expressing }\end{array}$ & Standard & No & $\begin{array}{l}\text { co-incubation with CEA } \\
\text { mRNA }\end{array}$ & 3 pts SD \\
\hline [65] & 42 & $\begin{array}{c}\text { Pancreatic cancer } \\
\text { cytotoxic lymphocytes } \\
\text { gemcitabine }\end{array}$ & Standard (6 days) & $\mathrm{TNF} \alpha$ & EP with MUC-1 mRNA & $\begin{array}{c}1 \text { pt with CR, } 3 \text { pts with PR, } 22 \text { pts with } \\
\text { SD16 pts with PD } \\
\text { mOS 13.9 months } \\
\text { 1-year survival rate } 51.1 \%\end{array}$ \\
\hline [54] & 37 & $\begin{array}{l}\text { CEA expressing cancer, } \\
\text { m ( } 24 \text { tumor bearing, } \\
13 \text { tumor free })\end{array}$ & Standard & No & $\begin{array}{l}\text { co-incubation with CEA } \\
\text { mRNA }\end{array}$ & 1 pt CR, 2 pts PR, 2 pts SD \\
\hline [29] & 15 & Colorectal cancer, $\mathrm{m}$ & $\begin{array}{l}\text { Standard (including } \\
\text { FCS) }\end{array}$ & No & co-incubation with aT-RNA & No objective clinical response \\
\hline$[55]$ & 5 & Colorectal cancer, $\mathrm{m}$ & Standard & MCMM & EP with CEA mRNA & $\begin{array}{l}\text { Median progression free survival of } \\
26 \text { months }\end{array}$ \\
\hline$[30]$ & 1 & Adenocarcinoma, $\mathrm{m}$ & Standard & $\mathrm{TNF} \alpha$ & lipofection of aT-RNA & No objective clinical response \\
\hline [51] & 12 & Multiple myeloma & Standard & MCMM & $\begin{array}{l}\text { EP with BCMA, MAGE3, } \\
\text { and survivin mRNA }\end{array}$ & $\begin{array}{l}\text { After } 25 \text { months } 10 \text { of } 12 \text { pts still alive } \\
\text { with } 5 \text { pts having SD, } 5 \text { pts having PD }\end{array}$ \\
\hline [58] & 21 & AML & ns & ns & $\begin{array}{l}\text { EP with hTERT mRNA, }+/- \\
\text { LAMP }\end{array}$ & $\begin{array}{l}\text { "vaccination with hTERT-DCs may be } \\
\text { associated with favorable } \\
\text { recurrence-free survival" }\end{array}$ \\
\hline
\end{tabular}


Table 2. Cont.

\begin{tabular}{|c|c|c|c|c|c|c|}
\hline $\begin{array}{c}\text { Study } \\
\text { Reference }\end{array}$ & \# Pts & $\begin{array}{c}\text { Disease and } \\
\text { Combination Treatment }\end{array}$ & DC Culturing & Maturation & RNA-Transfection & Clinical Response \\
\hline [64] & 30 & AML & Standard (6 days) & $\mathrm{TNF} \alpha+\mathrm{PGE}_{2}$ & $\begin{array}{l}\text { EP with WT1 mRNA +/- } \\
\text { DC-lamp }\end{array}$ & $\begin{array}{l}9 \text { pts with molecular remission } \\
\quad 4 \text { pts with SD } \\
\text { relapse reduction rate of } 25 \%\end{array}$ \\
\hline [68] & 7 & $\begin{array}{l}4 \text { healthy volunteers, } \\
3 \text { HSCT recipients }\end{array}$ & $\begin{array}{l}\text { Standard (6 days } \\
\text { clinimacs) }\end{array}$ & $\mathrm{TNF} \alpha, \mathrm{PGE}_{2}$ & EP with CMV pp65 mRNA & $\begin{array}{l}\text { No survival data (vaccination to induce } \\
\text { CMV cellular response) }\end{array}$ \\
\hline [67] & 12 & $\begin{array}{c}\text { HCV-related } \\
\text { hepato-carcinoma }\end{array}$ & Standard & $\mathrm{TNF} \alpha$ & EP with HSP70 mRNA & 2 pts with CR (min. 33 and 44 months) \\
\hline [72] & 10 & HIV infection & Standard & $\begin{array}{l}\text { TNF } \alpha+\mathrm{IFN} \gamma+ \\
\mathrm{PGE}_{2}+\mathrm{CD} 40 \mathrm{~L} \\
\text { mRNA }\end{array}$ & $\begin{array}{l}\text { EP with Gag, Vpr, Rev, } \\
\text { and Nef mRNA }\end{array}$ & $\begin{array}{l}7 \text { pts HIV-specific proliferative immune } \\
\text { response }\end{array}$ \\
\hline [74] & 17 & HIV infection & Standard (6 days) & MCMM & $\begin{array}{c}\text { EP with Tat-, Rev-, } \\
\text { or Nef-DC-Lamp mRNA }\end{array}$ & Vaccine-specific immune response \\
\hline [75] & 6 & HIV infection & Standard (clinimacs) & $\mathrm{TNF} \alpha+\mathrm{PGE}_{2}$ & $\begin{array}{c}\text { EP with Gag-DC-Lamp or } \\
\text { Tat-Rev-Nef-DC-Lamp } \\
\text { mRNA }\end{array}$ & Vaccine-specific immune response \\
\hline [71] & 10 & HIV infection & Standard (5 days) & MCMM & EP with Gag and Nef mRNA & $\begin{array}{l}\text { increased but short-lived CD4-responses } \\
\text { against HIV gag and nef }\end{array}$ \\
\hline [73] & 35 & HIV infection & Standard & $\begin{array}{c}\mathrm{TNFa}+\mathrm{IFN} \gamma+ \\
\mathrm{PGE}_{2}+ \\
\text { CD40L-mRNA }\end{array}$ & $\begin{array}{l}\text { EP with Gag, Vpr, Rev, } \\
\text { and Nef mRNA }\end{array}$ & none \\
\hline \multicolumn{7}{|c|}{$\begin{array}{l}\text { m: metastatic, pt(s): patient(s), ns: not specified, St.: stage, EP: electroporation, IP: immunoproteasome, (m)OS: (median) overall survival, (m)RFS: (median) relapse free survival; (m)PFS: } \\
\text { (median) progression free survival, CR: complete response, PR: partial response, SD: stable disease, PD: progressive disease, HSCT: haematopoietic stem cell transplantation, MCM: } \\
\text { monocyte-conditioned medium, MCMM = MCM-mimic (TNF } \alpha \text {, IL-1, IL-6, PGE }) \text {, aT-RNA: autologous tumor RNA, aTSC-RNA: autologous tumor stem cell RNA, AML: acute myeloid } \\
\text { leukemia, MAGE: melanoma-associated antigen, Lamp: lysosome-associated membrane protein, hTERT: human telomerase reverse transcriptase, BCMA: B-cell maturation antigen, MUC1: } \\
\text { mucin 1, CEA: carcinoembryonic antigen, PSA: prostate-specific antigen, PAP: prostatic acid phosphatase, WT1: Wilms Tumor 1, CMV: cytomegalovirus, HSP70: heat-shock protein 70, } \\
\text { Gag: HIV group-specific antigen, Vpr: HIV viral protein R, Rev: HIV reverse transcriptase, Nef: HIV negative regulatory factor, Tat: HIV trans-activator of transcription, ns: not specified. } \\
\text { Standard = Monocytes cultured in GM-CSF and IL-4 (default = } 7 \text { days). }\end{array}$} \\
\hline
\end{tabular}


Table 3. Adverse events in trials using DCs loaded with mRNA.

\begin{tabular}{|c|c|c|c|c|c|}
\hline $\begin{array}{c}\text { Study } \\
\text { (Reference) }\end{array}$ & \# Pts & $\begin{array}{c}\text { Disease }+ \text { Combination } \\
\text { Treatment }\end{array}$ & Transfection & Route and Target Dose & Safety Summary \\
\hline [35] & 6 & Melanoma, stage IV & EP with aT-RNA & $\begin{array}{c}5 \times 10^{6} \text { sc in } 3 \text {-weekly intervals } \\
\text { for } 4 \text { cycles }\end{array}$ & $\begin{array}{c}2 \text { pts with fatigue (1 grade I, } 1 \text { grade II), } 2 \text { pts with } \\
\text { nausea (1 grade I, } 1 \text { grade II), } 1 \text { pt with anorexia } \\
\text { (grade II), } 1 \text { pt with arthralgia (grade I), } 1 \text { pt with } \\
\text { confusion (grade I), } 2 \text { pts with diarrhea (grade I), } \\
1 \text { pt with hemorrhage (grade I), } 1 \text { pt with local } \\
\text { reaction (grade I), } 1 \text { pt with myalgia (grade II), } 1 \text { pt } \\
\text { with abdominal pain (grade II), } 1 \text { pt with bone pain } \\
\text { (grade I), } 1 \text { pt with speech disorder (grade I), } 1 \text { pt } \\
\text { with vomiting (grade I), } 1 \text { pt with wound infection } \\
\text { (grade I) }\end{array}$ \\
\hline$[44]$ & 11 & Melanoma stage III & $\begin{array}{l}\text { EP with gp100 or } \\
\text { tyrosinase mRNA }\end{array}$ & $\begin{array}{c}1.5 \times 10^{7} \text { in biweekly intervals for } \\
3 \text { cycles }\end{array}$ & No side effects described \\
\hline [41] & 35 & Melanoma, m & $\begin{array}{l}\text { EP with MAGE-A3,-C2, } \\
\text { tyrosinase, gp100 mRNA }\end{array}$ & $\begin{array}{c}4.3 \times 10^{7} \text { id } 4 \text { times in biweekly } \\
\text { intervals; further vaccinations in } \\
\text { case of residual vaccine after an } \\
8 \text { week interval }\end{array}$ & $\begin{array}{c}\text { all pts: local reaction (grade II) } \\
2 \text { pts fever, myalgia, and asthenia grade II }\end{array}$ \\
\hline [45] & 45 & Melanoma, m & $\begin{array}{l}\text { EP with gp100 and } \\
\text { tyrosinase mRNA }\end{array}$ & $\begin{array}{l}12 \times 10^{6} \text { cells } 3 \text { id times in } \\
\text { biweekly intervals; } 2 \text { maintenance } \\
\text { cycles for stable patients after } \\
6 \text { months respectively }\end{array}$ & $\begin{array}{l}\text { local reaction: } 23 \text { pts grade I, } 1 \text { pt grade II } \\
\text { flu like symptoms: } 20 \text { pts grade I, } 10 \text { pts grade II }\end{array}$ \\
\hline [49] & 12 & Melanoma, m & $\begin{array}{c}\text { EP with gp100, MelanA, } \\
\text { tyrosinase, } \\
\text { and MAGE-A3 mRNA } \\
\text { +/- IP siRNA }\end{array}$ & $\begin{array}{l}10^{7} \text { cells id } 6 \text { times in weekly } \\
\text { intervals }\end{array}$ & No adverse events observed \\
\hline [42] & 15 & Melanoma & $\begin{array}{c}\text { EP with gp100-, } \\
\text { tyrosinase-, MAGE-A3-, } \\
\text { and -C2-DC-Lamp mRNA }\end{array}$ & $\begin{array}{c}\text { Cohort 1: } 2 \times 10^{7} \mathrm{id}, 4 \times 10^{6} \mathrm{iv} \\
\text { Cohort 2: } 12 \times 10^{6} \mathrm{id}, 12 \times 10^{6} \mathrm{iv} \\
\text { Cohort 3: } 4 \times 10^{6} \mathrm{id}, 2 \times 10^{7} \mathrm{iv} \\
\text { Cohort } 4: 24 \times 10^{6} \mathrm{iv} \\
4 \text { vaccinations in biweekly } \\
\text { intervals, } 5 \text { th vaccination with } \\
10 \text { weeks interval }\end{array}$ & $\begin{array}{c}11 \text { pts local reaction grade II } \\
3 \text { pts chills grade II } \\
8 \text { pts flu like symptoms grade II } \\
3 \text { pts fever grade II }\end{array}$ \\
\hline
\end{tabular}


Table 3. Cont.

\begin{tabular}{|c|c|c|c|c|c|}
\hline $\begin{array}{c}\text { Study } \\
\text { (Reference) }\end{array}$ & \# Pts & $\begin{array}{c}\text { Disease }+ \text { Combination } \\
\text { Treatment }\end{array}$ & Transfection & Route and Target Dose & Safety Summary \\
\hline [46] & 15 & Melanoma & $\begin{array}{l}\text { EP with tyrosinase and } \\
\text { gp100 RNA }\end{array}$ & $\begin{array}{l}\text { Up to } 15 \times 10^{6} \text { cells i.n. } 3 \text { times } \\
\text { with maintenance cycles every } \\
6 \text { months }\end{array}$ & $\begin{array}{c}4 \text { pts local reaction grade I } \\
4 \text { pts flu like symptoms grade I }\end{array}$ \\
\hline$[40]$ & 30 & Melanoma (adjuvant) & $\begin{array}{c}\text { EP with MAGE-A1-, -A3-, } \\
\text {-C2-, tyrosinase-, MelanA-, } \\
\text { and gp100-DC-Lamp } \\
\text { RNA }\end{array}$ & $\begin{array}{c}\sim 24 \times 10^{6} \text { id } 4 \text { to } 6 \text { times in } \\
\text { biweekly intervals }\end{array}$ & $\begin{array}{c}30 \text { pts local reaction grade II } \\
1 \text { pt fever grade II } \\
1 \text { pt flu like symptoms } \\
7 \text { pts vitiligo }\end{array}$ \\
\hline [47] & 28 & Melanoma stage III and IV & $\begin{array}{l}\text { EP with gp100 and } \\
\text { tyrosinase mRNA }\end{array}$ & $\begin{array}{l}16 \text { pts: } 75 \times 10^{5} \text { to } 3 \times 10^{7} \text { iv }(2 / 3) \\
\text { and id }(1 / 3) \\
12 \text { pts: } 15 \times 10^{5} \text { to } 16 \times 10^{7} \\
\text { intranodally } \\
3 \text { biweekly vaccinations per cycle, } \\
\text { max } 2 \text { cycles in } 6 \text { months }\end{array}$ & $\begin{array}{c}\text { flu-like: } 11 \text { pts grade I, } 16 \text { pts grade II, } 1 \text { pt grade III } \\
\text { local reactions: } 12 \text { pts grade I, } 13 \text { pts grade II } \\
\text { Hepatotoxicity: } 9 \text { pts grade I, } 10 \text { pts grade II, } 5 \text { pts } \\
\text { grade III } \\
\text { pneumonitis: } 8 \text { pts } \\
\text { vitiligo } 1 \text { pt }\end{array}$ \\
\hline [37] & 31 & Advanced melanoma & EP with aT-RNA & $\begin{array}{c}4 \text { weekly injection } 2 \times 10^{7} \\
\text { intranodally }(21) \text { or id }(10) \text { then } \\
\text { one id. } 9 \text { intranodally injected } \\
\text { patients received IL-2 }\end{array}$ & $\begin{array}{l}\text { Mild flu-like symptoms in some pts, pain in tumor, } \\
\text { inflammatory reaction at injection site (grade I and } \\
\text { II) } \\
1 \mathrm{pt} \text { : vitiligo grade I } \\
\text { no long term toxicity }\end{array}$ \\
\hline$[50]$ & 22 & $\begin{array}{c}\text { Malignant } \\
\text { melanomacyclophosphamide }\end{array}$ & $\begin{array}{l}\text { EP with hTERT, survivin, } \\
\text { p53 mRNA }\end{array}$ & $\begin{array}{l}5 \times 10^{6} \text { intermitting with } \\
\text { cyclophosphamide for } 6 \text { cycles }\end{array}$ & $\begin{array}{l}\text { Grade III: } 1 \text { pt: lung embolus from } \\
\text { leukapheresis-catherization } \\
\text { Grade I and II: } 13 \text { pts fatigue, } 12 \text { pts nausea, } 7 \text { pts } \\
\text { diarrhea, } 5 \text { pts anemia, } 1 \text { pt neutropenia, } 1 \text { pt: } \\
\text { hyperthyroidism, } 1 \text { pt vitiligo, } 1 \text { pt myalgia. (all not } \\
\text { attributed to either vaccine or cyclophosphamide) }\end{array}$ \\
\hline [43] & 39 & $\begin{array}{l}\text { Pretreated advanced } \\
\text { melanoma Ipilimumab }\end{array}$ & $\begin{array}{c}\text { EP with MAGE-A3-, -C2-, } \\
\text { tyrosinase-, } \\
\text { and gp100-DC-LAMP } \\
\text { mRNA }\end{array}$ & $\begin{array}{c}4 \times 10^{6} \text { id and } 2 \times 10^{7} \text { iv } 1 \mathrm{~h} \text { after } \\
\text { Ipilimumab } \\
\text { first } 18 \text { patients received one does } \\
\text { DCs } 2 \text { weeks before Ipilimumab }\end{array}$ & $\begin{array}{l}\text { DC-related: } \\
\text { all pts: grade II injection site reactions } \\
15 \text { pts: grade I+II post-infusion chills } \\
33 \text { pts: grade I+II flu-like symptoms } \\
\text { ICB-related: } \\
\text { 14 pts: grade III+IV }\end{array}$ \\
\hline
\end{tabular}


Table 3. Cont

\begin{tabular}{|c|c|c|c|c|c|}
\hline $\begin{array}{c}\text { Study } \\
\text { (Reference) }\end{array}$ & \# Pts & $\begin{array}{c}\text { Disease }+ \text { Combination } \\
\text { Treatment }\end{array}$ & Transfection & Route and Target Dose & Safety Summary \\
\hline$[48]$ & 23 & Uveal melanoma & $\begin{array}{l}\text { EP with gp100 and } \\
\text { tyrosinase mRNA }\end{array}$ & $\begin{array}{l}\text { up to } 3 \text { cycles of } 3 \text { biweekly iv and } \\
\text { id injections in } 6 \text {-month intervals }\end{array}$ & $\begin{array}{l}21 \text { pts: grade I and II flu-like symptoms, } 20 \text { pts: } \\
\text { grade I and II local reactions, } 1 \text { pt vitiligo }\end{array}$ \\
\hline [60] & 1 & $\begin{array}{l}\text { Papillary ovarian cancer } \\
\text { stage IIIc }\end{array}$ & EP with folat-R-mRNA & $\begin{array}{l}2 \text { to } 50 \times 10^{6} \text { id in monthly } \\
\text { intervals for } 10 \text { cycles }\end{array}$ & No side effects \\
\hline$[62]$ & 2 & Ovarian cancer & EP with WT1 mRNA & $\begin{array}{l}7-61 \times 10^{6} \text { cells id } 4 \text { times in } \\
\text { weekly intervals in Imiquimod } \\
\text { pretreated skin }\end{array}$ & No signs of toxicity \\
\hline [63] & 6 & Uterine cancer & EP with WT1 mRNA & $\begin{array}{l}6-32 \times 10^{6} \text { cells id } 4 \text { times in } \\
\text { weekly intervals Imiquimod } \\
\text { pretreated skin }\end{array}$ & 6 pts local reaction grade I \\
\hline$[31]$ & 10 & $\begin{array}{l}\text { Stage III or IV renal cell } \\
\text { carcinoma after } \\
\text { nephrectomy }\end{array}$ & $\begin{array}{c}\text { No EP, co-incubation with } \\
\text { aT-RNA }\end{array}$ & $\begin{array}{c}8 \text { pts: } 10^{7} \text { iv }+10^{7} \text { id every } \\
2 \text { weeks for } 3 \text { cycles } \\
2 \text { pts: } 3 \times 10^{7} \text { iv }+10^{7} \text { id every } \\
2 \text { weeks for } 3 \text { cycles }\end{array}$ & $\begin{array}{c}5 \text { pts with local reaction (grade I), } \\
1 \text { pt with anemia, } 2 \text { pts with dyspnea (both grade I, } \\
\text { both considered unrelated to vaccine); }\end{array}$ \\
\hline [34] & 11 & $\begin{array}{c}\text { Renal cell cancer, } \\
\text { m (10 pts), ovarial } \\
\text { carcinoma (1pt) Ontak }^{\circledR} \\
(7 \mathrm{pts})\end{array}$ & EP with aT-RNA & $\begin{array}{l}10^{7} \text { id at biweekly intervals for } \\
3 \text { cycles }\end{array}$ & $\begin{array}{c}4 \text { pts with grade } 1 \text { rise of temperature and malaise } \\
\text { (after Ontak }{ }^{\circledR} \text { ) } \\
1 \text { pt with elevation of RF (after Ontak }{ }^{\circledR} \text { ) } \\
1 \text { pt with transient ALT elevation (after Ontak) }\end{array}$ \\
\hline [52] & 28 & $\begin{array}{l}\text { Renal cell cancer } \\
\text { cytokine-induced killer } \\
\text { cells }\end{array}$ & $\begin{array}{l}\text { EP with MUC-1 and } \\
\text { Survivin mRNA }\end{array}$ & $\begin{array}{c}2 \times 10^{7} \text { to } 5 \times 10^{7} \text { cells sc } 4 \text { times } \\
\text { in } 2 \text { days intervals }\end{array}$ & Flu like symptoms and fever grade I and II \\
\hline [36] & 21 & Renal cell cancer sunitinib & EP with aT-RNA & $14 \times 10^{6}$ cells & $\begin{array}{c}\text { Vaccine-related - all grade I or II: } \\
7 \text { pts: injection site erythema, } 5 \text { pts: Injection site } \\
\text { induration, } 4 \text { pts rash, } 3 \text { pts diarrhea, } 3 \text { pts fatigue, } \\
2 \text { pts nausea, } 2 \text { pts headache, } 1 \text { pt decreased weight, } \\
1 \text { pt hypertension, } 1 \text { pt dysgeusia }\end{array}$ \\
\hline
\end{tabular}


Table 3. Cont

\begin{tabular}{|c|c|c|c|c|c|}
\hline $\begin{array}{c}\text { Study } \\
\text { (Reference) }\end{array}$ & \# Pts & $\begin{array}{c}\text { Disease }+ \text { Combination } \\
\text { Treatment }\end{array}$ & Transfection & Route and Target Dose & Safety Summary \\
\hline [56] & 13 & Prostate cancer, $\mathrm{m}$ & $\begin{array}{l}\text { No EP, co-incubation with } \\
\text { PSA mRNA }\end{array}$ & $\begin{array}{c}3 \text { pts: } 10^{7} \mathrm{iv}+10^{7} \mathrm{id} \text { for } 3 \text { cycles } \\
3 \text { pts: } 3 \times 10^{7} \mathrm{iv}+10^{7} \mathrm{id} \text { for } \\
3 \text { cycles } \\
7 \text { pts: } 5 \times 10^{7} \mathrm{iv}+10^{7} \mathrm{id} \text { for } \\
3 \text { cycles } \\
2 \text { week intervals }\end{array}$ & $\begin{array}{c}4 \text { pts with local reaction (grade I) } \\
4 \text { pts with grade I fever accompanied by flu-like } \\
\text { symptoms following injection } \\
1 \text { pt with transiently elevated ANA and RF }\end{array}$ \\
\hline [39] & 19 & $\begin{array}{l}\text { Prostate cancer, androgen } \\
\text { resistant }\end{array}$ & $\begin{array}{l}\text { EP with allogeneic tumor } \\
\text { RNA (3 human cancer cell } \\
\text { lines) }\end{array}$ & $\begin{array}{c}2 \times 10^{7} \text { either intranodally (10 pts) } \\
\text { or id (9 pts) weekly for } 4 \text { cycles }\end{array}$ & $\begin{array}{l}\text { No grade II to IV side effects. } \\
\text { Erythema at injection sites, increased size of } \\
\text { draining lymph nodes, minor pain at injection site } \\
\text { or small increase in hot flushes. }\end{array}$ \\
\hline [57] & 20 & prostate cancer, $\mathrm{m}$ & $\begin{array}{l}\text { EP with hTERT mRNA } \\
+/- \text { LAMP }\end{array}$ & $\begin{array}{c}10^{7} \text { id in weekly intervals ( } 3 \text { or } \\
6 \text { cycles) }\end{array}$ & $\begin{array}{c}4 \text { pts with constitutional symptoms (grade I) like } \\
\text { fatigue or flu-like symptoms } \\
18 \text { pts with local reaction (grade I) } \\
2 \text { pts with transient elevation of ANA } \\
1 \text { pt with anemia and thrombocytopenia (grade III) } \\
\text { considered unrelated to therapy }\end{array}$ \\
\hline [59] & 21 & $\begin{array}{l}\text { Castration- resistant } \\
\text { prostate cancer Docetaxel }\end{array}$ & $\begin{array}{l}\text { EP with PSA, PAP, } \\
\text { survivin, hTERT mRNA }\end{array}$ & $\begin{array}{l}5 \times 10^{6} \text { twice during four } \\
\text { Docetaxel-cycles, then one for } \\
6 \text { cycles, then only DCs every } \\
3 \text { months at patient decision }\end{array}$ & $\begin{array}{c}\text { DC-related: } \\
\text { local rash and pain only } \\
\text { one pulmonary embolism related to leukapheresis } \\
\text { procedure }\end{array}$ \\
\hline [32] & 7 & Pediatric brain tumors & $\begin{array}{l}\text { No EP, co-incubation with } \\
\text { aT-RNA }\end{array}$ & $5 \times 10^{6} / \mathrm{m}^{2} \mathrm{iv}+5 \times 10^{6} / \mathrm{m}^{2} \mathrm{id}$ & No measurable toxicity, no signs of autoimmunity \\
\hline [33] & 8 & $\begin{array}{l}\text { Pediatric neuroblastoma } \\
\text { stage IV }\end{array}$ & $\begin{array}{l}\text { No EP, co-incubation with } \\
\text { aT-RNA }\end{array}$ & $5 \times 10^{6} / \mathrm{m}^{2} \mathrm{iv}+5 \times 10^{6} / \mathrm{m}^{2} \mathrm{id}$ & $\begin{array}{l}\text { No measurable toxicity, no signs of autoimmunity } \\
1 \text { pt with grade } 1 \text { skin reaction }\end{array}$ \\
\hline [38] & 7 & Glioblastoma & EP with aT-RNA & $\begin{array}{l}10^{7} \text { cells id; } 2 \text { vaccinations within } \\
\text { first week, followed by } \\
3 \text { vaccinations in weekly } \\
\text { intervals; rest of vaccinations in } \\
\text { monthly intervals }\end{array}$ & $\begin{array}{l}\text { fatigue: } 6 \text { pts grade I, } 1 \text { pt grade III } \\
5 \text { pts nausea/anorexia grade I } \\
\text { pain: } 3 \text { pts grade } 1,1 \text { pt grade II } \\
1 \text { pt constipation grade I }\end{array}$ \\
\hline
\end{tabular}


Table 3. Cont

\begin{tabular}{|c|c|c|c|c|c|}
\hline $\begin{array}{c}\text { Study } \\
\text { (Reference) }\end{array}$ & \# Pts & $\begin{array}{c}\text { Disease }+ \text { Combination } \\
\text { Treatment }\end{array}$ & Transfection & Route and Target Dose & Safety Summary \\
\hline [66] & 12 & $\begin{array}{l}\text { Glioblastoma injection site } \\
\text { preconditioned with } \\
\text { tetanus toxoid }\end{array}$ & $\begin{array}{l}\text { EP with CMV } \\
\text { pp65 mRNA }\end{array}$ & $\begin{array}{l}2 \times 10^{7} \text { cells id } 3 \text { times in } \\
\text { biweekly intervals followed by } \\
\text { monthly intervals }\end{array}$ & None \\
\hline [69] & 11 & $\begin{array}{l}\text { Glioblastoma } \\
\text { temozolimide DCs mixed } \\
\text { with GM-CSF }\end{array}$ & $\begin{array}{l}\text { EP with CMV } \\
\text { pp65 mRNA }\end{array}$ & $\begin{array}{l}\text { three times } 2 \times 10^{7} \text { in biweekly } \\
\text { intervals then monthly } 6 \text { to } \\
12 \text { times into the groin }\end{array}$ & $\begin{array}{l}\text { No AEs in response to DCs, but one grade III SAE in } \\
\text { response to the co-injected GM-CSF }\end{array}$ \\
\hline [70] & 9 & $\begin{array}{l}\text { Glioblastoma adoptive } \\
\text { T-cell transfer }\end{array}$ & $\begin{array}{l}\text { EP with CMV } \\
\text { pp65 mRNA }\end{array}$ & $\begin{array}{l}\text { three times } 2 \times 10^{7} \text { in biweekly } \\
\text { intervals iv }\end{array}$ & $\begin{array}{c}2 \text { pts reduced CD4 count (grade II), } \\
1 \text { pt reduced platelet count (grade I) } \\
1 \text { pt reduced Neutrophil and WBC count (grade II) } \\
1 \text { pt reduced hematocrit (grade I) }\end{array}$ \\
\hline [53] & 3 & $\begin{array}{l}\text { Pancreatic } \\
\text { adenocarcinoma CEA } \\
\text { expressing }\end{array}$ & $\begin{array}{l}\text { No EP, co-incubation with } \\
\text { CEA mRNA }\end{array}$ & $\begin{array}{l}10^{7} \text { loaded and } 10^{7} \text { unloaded DCs } \\
\text { id monthly for } 6 \text { cycles }\end{array}$ & $\begin{array}{l}1 \mathrm{pt} \text { with liver abscess, } 1 \mathrm{pt} \text { with upper respiratory } \\
\text { infection (both considered unrelated to vaccine) }\end{array}$ \\
\hline$[65]$ & 42 & $\begin{array}{l}\text { Pancreatic cancer } \\
\text { cytotoxic lymphocytes } \\
\text { gemcitabine }\end{array}$ & EP with MUC-1 mRNA & $\begin{array}{l}4 \times 10^{5} \text { to } 39 \times 10^{6} \text { cells id in } \\
\text { monthly intervals }\end{array}$ & $\begin{array}{c}\text { several grade } 3 \text { and adverse events, but attributed to } \\
\text { T-cell transfer }\end{array}$ \\
\hline$[54]$ & 37 & $\begin{array}{l}\text { CEA expressing cancer m } \\
\text { (24 tumor bearing, } \\
13 \text { tumor free })\end{array}$ & $\begin{array}{l}\text { No EP, co-incubation with } \\
\text { mRNA encoding CEA }\end{array}$ & $\begin{array}{c}11 \text { pts: } 10^{7} \text { iv weekly for } 4 \text { weeks } \\
4 \text { pts: } 3 \times 10^{7} \text { iv }+10^{6} \text { id every } \\
2 \text { weeks for } 4 \text { cycles } \\
14 \text { pts: } 10^{8} \text { iv }+10^{6} \text { id every } \\
2 \text { weeks for } 4 \text { cycles } \\
8 \text { patients additionally received } \\
1.2 \times 10^{6} \text { units IL-2 s.c. } \\
\text { group } 2: 13 \text { pts: } 3 \times 10^{7} \text { iv }+10^{6} \\
\text { id every } 2 \text { weeks for } 4 \text { cycles }\end{array}$ & $\begin{array}{c}\text { No acute toxicities (no evidence of anaphylactic } \\
\text { reactions or other cardiopulmonary compromise) } \\
\text { Rise of body temperature of } 0.28^{\circ} \mathrm{C}\left(0.5^{\circ} \mathrm{F}\right) \\
\text { Rise of mean arterial pressure of } 6 \mathrm{~mm} \mathrm{Hg} \\
\text { Unrelated or tumor-related: } \\
1 \text { pt with rise in hepatic transaminases (from grade I } \\
\text { to grade III) } \\
1 \text { pt with myelodysplastic syndrome } 6 \text { months after } \\
\text { completing therapy } \\
1 \text { pt with an upper extremity deep vein thrombosis }\end{array}$ \\
\hline [29] & 15 & Colorectal cancer, $\mathrm{m}$ & co-incubation aT-RNA & $\begin{array}{l}4 \times 10^{6} \text { iv every } 4 \text { weeks for } \\
4 \text { cycles }\end{array}$ & 2 pts with transient rigor and malaise \\
\hline [55] & 5 & Colorectal cancer, $\mathrm{m}$ & EP with CEA mRNA & $\begin{array}{c}5 \times 10^{6} \text { id, } 1.1 \times 10^{7} \text { iv on day } 0 \\
7 \text { and } 15.3 \text { cycles. }\end{array}$ & $\begin{array}{c}\text { Flu like symptoms grade I, fever grade I, local } \\
\text { reaction grade I }\end{array}$ \\
\hline
\end{tabular}


Table 3. Cont.

\begin{tabular}{|c|c|c|c|c|c|}
\hline $\begin{array}{c}\text { Study } \\
\text { (Reference) }\end{array}$ & \# Pts & $\begin{array}{c}\text { Disease }+ \text { Combination } \\
\text { Treatment }\end{array}$ & Transfection & Route and Target Dose & Safety Summary \\
\hline$[30]$ & 1 & Adenocarcinoma, $\mathrm{m}$ & $\begin{array}{l}\text { No EP, lipofection of } \\
\text { aT-RNA }\end{array}$ & $\begin{array}{c}3 \times 10^{7} \text { iv }+10^{6} \text { id every } 4 \text { weeks } \\
\text { for } 4 \text { cycles }\end{array}$ & No toxicities observed \\
\hline$[51]$ & 12 & Multiple myeloma & $\begin{array}{l}\text { EP with BCMA, MAGE3, } \\
\text { and survivin mRNA }\end{array}$ & $\begin{array}{l}15 \times 10^{6} \text { cells iv and } 8 \times 10^{6} \text { cells } \\
\text { id } 3 \text { times in biweekly intervals }\end{array}$ & $\begin{array}{c}8 \text { pts local reaction grade I } \\
10 \text { pts fever, chills, malaise, muscle pain grade I/II }\end{array}$ \\
\hline [58] & 21 & AML & $\begin{array}{l}\text { EP with hTERT mRNA, } \\
+/- \text { LAMP }\end{array}$ & $\begin{array}{c}3 \text { to } 32 \text { vaccinations with } 10^{7} \mathrm{DCs}, \\
\text { first } 6 x \text { in weekly intervals later } \\
\text { biweekly }\end{array}$ & $\begin{array}{l}1 \text { pt idiopathic thrombocytopenia purpura (grade III) } \\
\text { no other severe toxicities reported }\end{array}$ \\
\hline$[64]$ & 30 & AML & $\begin{array}{l}\text { EP with WT1 mRNA +/- } \\
\text { DC-Lamp }\end{array}$ & $\begin{array}{c}5 \times 10^{6}, 10^{7} \text { or } 2 \times 10^{7} \text { cells id in } \\
\text { biweekly intervals followed by } \\
\text { bimonthly vaccinations }\end{array}$ & $\begin{array}{l}\text { all pts: local reaction at injection site (grade I) } \\
1 \text { pt pain in draining lymph nodes } \\
1 \text { pt drop of platelet count after 1st vaccination } \\
1 \text { pt flare up of pre-existing inflammation of the } \\
\text { Achilles tendon }\end{array}$ \\
\hline [67] & 12 & $\begin{array}{l}\text { HCV-related } \\
\text { hepato-carcinoma }\end{array}$ & EP with HSP70 mRNA & $\begin{array}{c}3 \text { times } 10^{7} \text { to } 3 \times 10^{7} \text { with } 3 \text { week } \\
\text { interval }\end{array}$ & $\begin{array}{c}1 \text { pt: grade I: ALT/AST increase } \\
3 \text { pts grade II: hyperglycemia, ALT increase, } \\
\text { ALT/AST increase } \\
1 \text { pt grade III liver abscess (not treatment related) }\end{array}$ \\
\hline [72] & 10 & HIV infection & $\begin{array}{l}\text { EP with Gag, Vpr, Rev } \\
\text { and Nef mRNA }\end{array}$ & $\begin{array}{l}10^{7} \text { id in monthly intervals for } \\
4 \text { cycles }\end{array}$ & $\begin{array}{l}6 \text { patients with either fatigue (grade I), or local } \\
\text { reaction at injection site (grade I), flu-like-symptoms } \\
\text { (grade I), one pt with each: headache (grade I), } \\
\text { diarrhea (grade I), axillary pain (grade I), RF } \\
\text { increase (grade I). nausea (grade 1), increase in } \\
\text { creatinine (grade I), hematochezia (grade I), } \\
\text { eye inflammation (grade I), insomnia (grade I), SCC } \\
\text { (grade II), reflux (grade II), GI pain (grade III), } \\
\text { appendicitis (grade III), anemia (grade I) }\end{array}$ \\
\hline [74] & 17 & HIV infection & $\begin{array}{l}\text { EP with Tat-DC-Lamp, } \\
\text { Rev-DC-Lamp or } \\
\text { Nef-DC-Lamp mRNA }\end{array}$ & $\begin{array}{l}3 \times 10^{7} \text { cells sc and id } 4 \text { times in } \\
4 \text { week intervals }\end{array}$ & 16 pts: local reactions (grade I) \\
\hline
\end{tabular}


Table 3. Cont

\begin{tabular}{|c|c|c|c|c|c|}
\hline $\begin{array}{c}\text { Study } \\
\text { (Reference) }\end{array}$ & \# Pts & $\begin{array}{c}\text { Disease }+ \text { Combination } \\
\text { Treatment }\end{array}$ & Transfection & Route and Target Dose & Safety Summary \\
\hline [75] & 6 & HIV infection & $\begin{array}{l}\text { Gag-DC-Lamp or } \\
\text { Tat-Rev-Nef-DC-Lamp } \\
\text { mRNA }\end{array}$ & $\begin{array}{c}10^{7} \text { cells sc (50\%) and id (50\%) } \\
4 \text { times in monthly intervals }\end{array}$ & $\begin{array}{c}1 \mathrm{pt} \text { fever } \\
6 \text { pts local reaction }\end{array}$ \\
\hline [68] & 7 & $\begin{array}{l}4 \text { healthy volunteers, } \\
3 \text { HSCT recipients }\end{array}$ & $\begin{array}{l}\text { EP with CMV } \\
\text { pp65 mRNA }\end{array}$ & $\begin{array}{l}4 \text { times } 10^{7} \text { (HTSC-patients) or } \\
10^{5}(\mathrm{HV}) \text { id at weekly intervals }\end{array}$ & $\begin{array}{c}7 \text { pts local reaction grade II (all) } \\
2 \text { HVs headache grade I } \\
1 \text { HV myalgia grade I } \\
1 \text { pt moderate gastrointestinal GVHD grade II } \\
\text { (HSCT) }\end{array}$ \\
\hline [71] & 10 & HIV infection & $\begin{array}{c}\text { EP with Gag and Nef } \\
\text { mRNA }\end{array}$ & $\begin{array}{c}4 \times 5 \times 10^{6}-15 \times 10^{6} \text { DCs at week } \\
0,2,6,10\end{array}$ & no AEs larger grade II \\
\hline [73] & 35 & HIV infection & $\begin{array}{l}\text { EP with Gag, Vpr, Rev, } \\
\text { and Nef mRNA }\end{array}$ & $\begin{array}{l}4 \text { id-injections of at least } 10^{7} \text { DCs } \\
\text { with } 4 \text { week intervals }\end{array}$ & $\begin{array}{l}25 \text { pts local reactions (grade I) } \\
\text { possibly related: headache, nausea, depression } \\
\text { dizziness vivid dreams lymphadenopathy, rashes }\end{array}$ \\
\hline
\end{tabular}




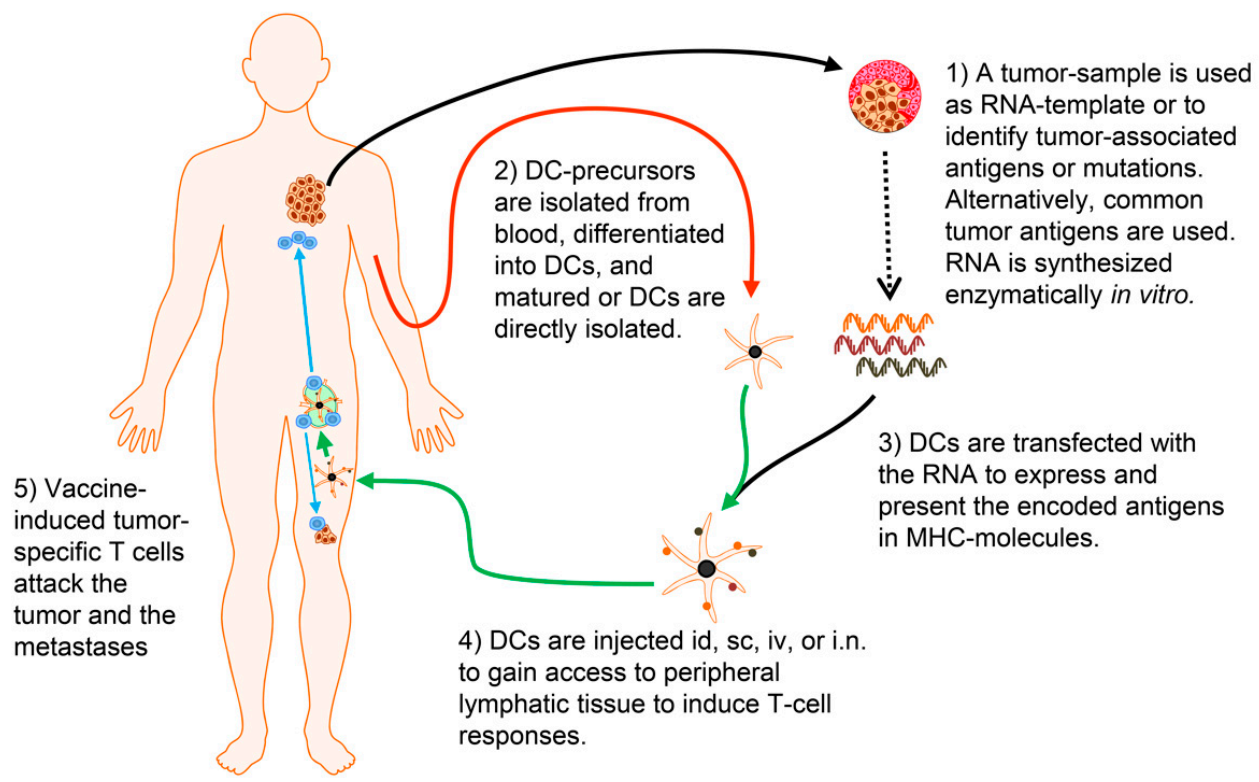

Figure 2. Concept of therapeutic vaccination with mRNA-transfected DCs. (1) Tumor material is isolated by surgery or biopsy. From this material, mRNA can be directly isolated. This RNA is usually amplified via a PCR-based method to gain sufficient amounts of mRNA. The tumor material can also be analyzed by sequencing, immunohistology, or other methods to identify antigens associated with this tumor, including somatic mutations. New bioinformatical methods can be used to identify the most promising T-cell epitopes for each individual patient. mRNA molecules that encode these antigens are transcribed in vitro from plasmid templates. (2) Cells (usually monocytes) that can be differentiated into DCs in vitro are isolated from the patient's blood. Alternatively, DCs, which are present in the blood, can be used. These DCs are matured to become immunogenic. (3) DC are transfected with the RNA to express the encoded tumor antigens. The DCs' own processing machinery degrades and presents the included T-cell epitopes in MHC. (4) The DCs are injected into the patient. Intradermal (id) and subcutaneous (sc) injection require migration via the lymphatic vessels towards the draining lymph node. Intravenous (iv) injection necessitates the transfer from the blood stream into lymphatic tissue. The direct injection into lymph nodes (i.n.) is an elegant approach, but is technically very difficult. (5) If the vaccine is successful, the DCs present the tumor-specific epitopes to T cells which are activated and attack the malignant tissue. Usually the DCs are injected repetitively to boost and maintain the responses. (The Motifolio Scientific Illustration Toolkit was used for the generation of this figure).

Defined non-mutated antigens were used in most clinical trials with RNA-transfected dendritic cells and have proven immunogenic while autoimmunity was rarely observed, except for some cases of vitiligo in melanoma patients immunized with antigens expressed in both melanoma cells and melanocytes.

In the early studies with RNA-loaded dendritic cells, a simple co-incubation of DCs and RNA as opposed to electroporation was used. Since 2005, however, electroporation has commonly been used as a method to actively introduce mRNA into cytoplasm of the DCs. A total of 47 publications so far have described clinical phase I and II trials using RNA-loaded DCs to treat cancer and virus-infections. Within those, 781 treated patients were described. Most of those suffered from cutaneous melanoma (289) followed by viral infections (85), urogenital (79), and prostate cancer (73). For the complete summary, please see Table 1 . In 10 of these trials, cells were loaded with autologous tumor-RNA, one used allogenic tumor RNA, and the other 36 used various defined antigens (Table 1).

The last publication in a clinical trial with RNA-loaded dendritic cells dates back to 2018. However, several active clinical trials with mRNA-transfected DCs to treat cancer are listed in clinicaltrials.gov. By November 2019, 18 active trials (Table 4) were listed mainly performed in the US (8), followed by Belgium (3), and Norway (3). 
Table 4. Active clinical trials with RNA-transfected DCs (from clinicaltrials.gov; status December 2019).

\begin{tabular}{|c|c|c|c|c|c|c|}
\hline NCT-Number & Country & Title & Antigen & Transfection * & Phase & Status \\
\hline NCT01983748 & Germany & Dendritic Cells Plus Autologous Tumor RNA in Uveal Melanoma & aT-RNA & EP & III & recruiting \\
\hline NCT03615404 & USA & $\begin{array}{l}\text { Cytomegalovirus (CMV) RNA-Pulsed Dendritic Cells for Pediatric Patients and Young } \\
\text { Adults with WHO Grade IV Glioma, Recurrent Malignant Glioma, or Recurrent } \\
\text { Medulloblastoma }\end{array}$ & CMV-pp65-LAMP & pulsed & I & active, not recruiting \\
\hline NCT02405338 & Norway & DC Vaccination for Post-remission Therapy in AML & WT1 Prame & transfected & $\mathrm{I} / \mathrm{II}$ & active, not recruiting \\
\hline NCT02465268 & USA & Vaccine Therapy for the Treatment of Newly Diagnosed Glioblastoma Multiforme & CMV pp65-LAMP & pulsed & II & recruiting \\
\hline NCT02649582 & Belgium & Adjuvant Dendritic Cell-Immunotherapy Plus Temozolomide in Glioblastoma Patients & WT1 & loaded & $\mathrm{I} / \mathrm{II}$ & recruiting \\
\hline NCT01456104 & USA & $\begin{array}{l}\text { Immune Responses to Autologous Langerhans-Type Dendritic Cells Electroporated with } \\
\text { mRNA Encoding a Tumor-Associated Antigen in Patients With Malignancy: A } \\
\text { Single-Arm Phase I Trial in Melanoma }\end{array}$ & mTRP2 & EP & I & active, not recruiting \\
\hline NCT03083054 & Brazil & $\begin{array}{l}\text { Cellular Immunotherapy for Patients with High Risk Myelodysplastic Syndromes and } \\
\text { Acute Myeloid Leukemia }\end{array}$ & WT1 & EP & $\mathrm{I} / \mathrm{II}$ & active, not recruiting \\
\hline NCT04157127 & USA & $\begin{array}{l}\text { Th-1 Dendritic Cell Immunotherapy Plus Standard Chemotherapy for Pancreatic } \\
\text { Adenocarcinoma }\end{array}$ & ns & loaded & I & not yet recruiting \\
\hline NCT01995708 & USA & $\begin{array}{l}\text { CT7, MAGE-A3, and WT1 mRNA-electroporated Autologous Langerhans-type Dendritic } \\
\text { Cells as Consolidation for Multiple Myeloma Patients Undergoing Autologous Stem Cell } \\
\text { Transplantation }\end{array}$ & Mage-A3, Mage-C1, WT1 & EP & I & active, not recruiting \\
\hline NCT01197625 & Norway & Vaccine Therapy in Curative Resected Prostate Cancer Patients & aT-RNA, hTERT, survivin & loaded & $\mathrm{I} / \mathrm{II}$ & active, not recruiting \\
\hline NCT01686334 & Belgium & $\begin{array}{l}\text { Efficacy Study of Dendritic Cell Vaccination in Patients with Acute Myeloid Leukemia in } \\
\text { Remission }\end{array}$ & WT1 & $\mathrm{EP}$ & II & recruiting \\
\hline NCT03548571 & Norway & $\begin{array}{c}\text { Dendritic Cell Immunotherapy Against Cancer Stem Cells in Glioblastoma Patients } \\
\text { Receiving Standard Therapy }\end{array}$ & aTSC-RNA, survivin, hTERT & transfected & $\mathrm{II} / \mathrm{III}$ & recruiting \\
\hline NCT02366728 & USA & DC Migration Study for Newly Diagnosed GBM & CMV pp65-LAMP & pulsed & II & active, not recruiting \\
\hline NCT02808416 & China & Personalized Cellular Vaccine for Brain Metastases (PERCELLVAC3) & ns & pulsed & I & active, not recruiting \\
\hline NCT02649829 & Belgium & Autologous Dendritic Cell Vaccination in Mesothelioma & WT1 & loaded & $\mathrm{I} / \mathrm{II}$ & recruiting \\
\hline NCT00639639 & USA & Vaccine Therapy in Treating Patients with Newly Diagnosed Glioblastoma Multiforme & CMV pp65-LAMP & loaded & I & active, not recruiting \\
\hline NCT02709616 & China & Personalized Cellular Vaccine for Glioblastoma (PERCELLVAC) & individually selected TAAs & pulsed & I & active, not recruiting \\
\hline NCT03927222 & USA & $\begin{array}{l}\text { Immunotherapy Targeted Against Cytomegalovirus in Patients with Newly Diagnosed } \\
\text { WHO Grade IV Unmethylated Glioma }\end{array}$ & CMV pp65-LAMP & pulsed & II & recruiting \\
\hline
\end{tabular}

* unfortunately, some researchers do not specify the method of transfection, although most probably electroporation was used. GBM: glioblastoma multiforme, aT-RNA: autologous tumor RNA, aTSC-RNA: autologous tumor stem cell RNA, AML: acute myeloid leukemia, MAGE: melanoma-associated antigen, CT7: MAGE-C1, Lamp: lysosome-associated membrane protein, hTERT: human telomerase reverse transcriptase, WT1: Wilms Tumor 1, CMV: cytomegalovirus, LAMP: lysosome-associated membrane protein, mTRP2: murine tyrosinase-related peptide 2, ns: not specified, EP: electroporation. 


\subsection{Clinical Efficacy}

Within the large number of phase I/II DC trials that have been published, mixed responses (disappearance of some but not necessarily all metastases, also with appearance of new ones) and stabilization of disease were usually reported in a subset of patients. Objective responses, classically defined by disappearance of all tumors (CR) or a reduction of $\geq 50 \%$ (PR) were, however, less frequently observed. Interestingly, however, while overall response was found to be only $3.8 \%$ with non-DC-based cancer vaccines, in a much-debated article by Rosenberg et al., tumor regression was seen in $7.1 \%$ of patients receiving DC vaccination [95-97]. In select DC-vaccination trials, regressions were observed at higher rates, such as in DC-based vaccination for non-Hodgkin lymphoma targeting tumor-specific idiotype immunoglobulin (response rate of $31.6 \%[13,98]$ ), or in melanoma trials when DCs were loaded with dying autologous tumor cells to vaccinate against the total antigenic repertoire of the individual tumors $(20 \%$ overall response rate in stage IV melanomas $[99,100])$. These observations support the use of DC vaccines that target the antigenic repertoire of a given tumor as it can be achieved by loading DCs with total tumor mRNA as a technically more elegant approach which can be validated and thus be performed well under GMP conditions.

According to a review published by Ridgeway in 2003 [101], 78 of 98 analyzed trials included patient outcomes, although none of the clinical studies was designed to demonstrate the efficacy of the DC treatment. There was evidence of clinical response in at least one subject in 48 of the clinical trials, and one or more subjects experienced a complete response (CR) in 16 trials.

A review from Engell-Noerregaard et al. published in 2009 analyzed DC-based vaccination of patients with malignant melanoma [102]. A total of 38 articles were included for analysis, including 626 melanoma patients treated with DC-based vaccines. The objective response rate (CR and PR) was $9 \%$ with $20(3 \%)$ complete responses and $37(6 \%)$ partial responses. The clinical response rate (CR, $\mathrm{PR}$, and SD) was $30 \%$ with 133 patients (21\%) having stable disease. Apart from suggesting a clinical benefit in one third of the patients, the analysis was also interesting because it was found that SD was significantly associated with induction of antigen-specific T cells $(p=0.0003)$.

Regarding efficacy, it must, however, be emphasized that it has become clear that for active immunotherapies which lead to activation of tumor-specific $T$ cells by either specific active vaccination (Dendreon's first generation DC vaccine Provenge ${ }^{\mathrm{TM}}$ [103]) or antigen-unspecific immune activation by taking off the brake from the immune system (anti-CTL-A4 treatment with Ipilimumab ${ }^{\mathrm{TM}}[104$, 105]), prolonged overall survival does not necessarily require regressions as defined by classical response criteria. Researchers in the cancer vaccine field were the first to point to this possibility. Indeed, the Provenge ${ }^{\mathrm{TM}} \mathrm{DC}$ vaccine phase III trials provided the first proof for this concept because time to progression was not significantly prolonged while OS was, so that finally this vaccine got approved by the FDA for the treatment of androgen-independent, metastatic prostate cancer. Treatment with the anti-CTL-A4 antibody Ipilimumab ${ }^{\mathrm{TM}}$ in phase II and the subsequently published phase III trial exhibited 4 response patterns associated with survival, with only two of them corresponding to classical regressions [104].

In retrospect, one has to state that it was very optimistic to expect DC vaccines or any other cancer vaccine (such as fashionable neo-antigen vaccines [106]) by themselves to frequently produce significant clinical benefit in the setting of established late stage malignancies like stage IV melanoma, given the increasing evidence that the tumor microenvironment dictates whether tumor-specific T-cell responses will successfully alter the course of the disease [107-109] as checkpoint molecules suppress spontaneously arising or vaccine-induced T cells. Nevertheless, the reported clinical responses with mRNA-transfected DCs are at least encouraging. Table 3 summarizes efficacy data from all published clinical trials using RNA-loaded DCs.

In the setting of stage IV melanoma, i.e., significant tumor-load, and also many other tumors, the use of DC vaccines, which are reliably immunogenic, is, therefore, now best explored in combination with other treatments such as anti-CTL-A4 and anti-PD1 treatment. In contrast, it is timely to test in randomized trials immunogenic DC vaccines alone in the setting of minimal tumor load as performed 
in the adjuvant treatment of resected monosomy 3 uveal melanoma patients (NCT01983748), because in this setting clinical benefit is a more realistic possibility.

\subsection{Safety of DC Vaccine Therapy}

In general, DC-based vaccination is well tolerated, and few severe side effects have been reported. The events most often reported after vaccination with antigen-loaded dendritic cells are local reactions at the dendritic cell injection sites, flu-like symptoms (fever, chills, headache, and myalgia) and fatigue. These immune-related symptoms are meanwhile considered to be reactogenicity to the vaccine, and are valued as a sign of the immunostimulatory effectiveness of the treatment. The local symptoms observed after subcutaneous or intradermal application are usually absent at onset but appear upon repetitive vaccination indicating accumulation of $\mathrm{T}$ cells at the injection site/draining lymph node, the systemic symptoms fatigue and increase of temperature probably being an effect of cytokines released.

In about $20 \%$ of our patients infused with standard DCs, we have ourselves observed grade 1 to 2 flu-like reactions (including fever up to $39.4{ }^{\circ} \mathrm{C}$ ) and constitutional symptoms within the first $72 \mathrm{~h}$ after infusion. Such side effects resolved upon treatment with paracetamol (usually $1 \mathrm{~g}$ administered i.v. followed by oral application) within $8 \mathrm{~h}$. This delayed reaction resembles a mild grade $1 \mathrm{CRS}$ (cytokine release syndrome), which is caused by T-cell activation and mediated by the release of pro-inflammatory cytokines into the plasma such as IL-1, TNF $\alpha$, and IL-6. Indeed, we detected an increase of these cytokines in the blood of those patients who were vaccinated with standard DC and developed transient fever from $6 \mathrm{~h}$ after DC vaccination onwards.

Severe autoimmune side effects/immune-related adverse events (IRAE) — as now often observed as toxic side effect of anti-CTL-A4 [105] and anti-PD1 therapy-have not been a safety issue in the context of DC vaccination, even in patients vaccinated for prolonged periods including patients with tumor regressions. The induction of severe autoimmunity-related side effects is theoretically possible with DC-based immunotherapy. In the case of DC vaccines, so far, the induction of autoantibodies without clinical symptoms has been observed occasionally. Induction of overt autoimmune diseases, with the exception of the occurrence of cosmetically troublesome, yet otherwise harmless vitiligo caused by the spotty destruction of skin melanocytes has, however, not been described.

The absence of autoimmune side effects is, however, not due to the fact that DCs were not sufficiently immunogenic. Cosmetically disturbing vitiligo resulting from destruction of melanocytes in the skin was regularly observed in a small number of patients after vaccination with DC loaded with melanocyte differentiation peptides; yet no other organ damage occurred. As expected, this side effect has also been observed with DCs loaded with mRNA including total mRNA. Out of 31 patients vaccinated with monocyte-derived DC loaded with autologous tumor-RNA, 1 patient developed vitiligo [37]. In one of our phase I trials with stage IV melanoma patients (NCT00126685), 1 out of 8 fully evaluable patients developed vitiligo after vaccination with DC loaded with autologous tumor RNA. Within another phase I/II trial, 9 patients out of 42 developed vitiligo after vaccination with DC, electroporated with MelanA, Mage-A3, and survivin mRNA.

What has been additionally observed in DC trials are laboratory abnormalities including positive anti-nuclear antibody tests [16,19,56,57,110-116], positive anti-dsDNA [111], positive anti-thyroid antibody tests $[16,113,117,118]$, and positive rheumatoid factor [56,110,115,116,119]. Apart from four cases of thyroiditis [110], development of autoimmune antibodies was, however, not associated with clinically manifested autoimmune disorders such as systemic lupus erythematosus, rheumatoid arthritis, or dermatomyositis. In a trial using allogeneic DCs loaded with autologous renal cell carcinoma lysate, one patient experienced WHO grade IV thrombocytopenia [120], but it remained unclear whether thrombocytopenia was a side effect of the drug cyclophosphamide used in this trial too, from paraneoplastic origin, or triggered/aggravated by the allogeneic cell therapy.

Side effects observed in 46 publications describing the experience with DCs loaded with either defined RNA or RNA extracted from tumor cells (Table 4) did not significantly differ from those observed in the larger number of trials employing also monocyte-derived DCs but loaded by other 
methods but introduction of antigen mRNA (such as co-incubation with peptides or dead tumor cells). In the 781 patients treated with mRNA-loaded DCs, SAEs of more than grade II rarely occurred (Table 4). Often the attribution of such SAEs to the administered DCs has not been clear [57,58,69]. In one case, fatigue grade III occurred [38]. One study that must be mentioned here was recently described by Bol et al. [47]. They combined adjuvants from conventional preventive vaccines with DCs which resulted in heavy side effects including grade III flu-like symptoms, local reactions including purulent discharge and liver toxicity. All these symptoms were transient in nature and can be clearly attributed to the use of the adjuvants, because side effects of such extent have never been observed before, and were never observed afterwards.

Overall, the safety profile of DC vaccination including DCs transfected with mRNA is very good-notably as compared to any other treatment regimen for advanced malignancies.

\subsection{Challenges and Future Perspectives of DC Vaccine Therapy}

Although, as described above, DC vaccine therapy has clear merits, it is a very personalized medicinal product, requiring well-educated staff and a GMP-compliant facility for production, limiting its application. Depending on which source of mRNA is used for the transfection of the DCs, the costs and applicability can differ. For example, to gain a completely individualized product using autologous amplified total tumor RNA and autologous DCs, one has to obtain enough tumor RNA to perform the amplification procedure, and the RNA has to be produced for each patient. The same is true for the application in which individually mutated mRNAs are picked for the transfection, which additionally causes high costs for the sequencing of the tumor to find these mutations. On the other side, an off-the-shelf approach can also be chosen by using prepared mRNAs encoding non-mutated antigens often expressed in the tumor, which reduces the costs to some extent. Nonetheless, we strongly believe that the merits of mRNA-DC vaccine therapy overrule the above-mentioned disadvantages.

Adding DC vaccination to any of the standard therapies seems reasonable, since there is sound evidence that these standard regimens will enhance the T-cell induction by vaccination so that an enhanced clinical effect is possible, and a negative impact of the DC vaccine regarding clinical benefit of the standard therapy is unlikely. Importantly, there is no evidence for significant enhancement of undesired side effects as cancer vaccines including DC vaccines have been used without unexpected or clearly enhanced toxicity problems in man together with chemotherapy [121-124], as well as immune checkpoint blockade (ICB) [43,81,125-128]. With respect to combination with checkpoint blockade, anti-PD-1 is a preferred backbone for combinations with small molecules and immune stimulatory agents, but for resistant tumors (like uveal melanoma) double checkpoint blockade is used for triplet therapies as a novel concept. This is evidenced by a search in clinicaltrials.gov, which shows over 120 phase I triplet trials.

Among the 39 melanoma phase I trials employing double checkpoint blockade, there are combinations with HDACi, IDOi, etc., but 15/39 melanoma studies involve additional immune stimulatory drugs such as cytokines (hu14.18-IL2, NKTR-214 IL-2, IL-15) or vaccine-like stimulatory agonistic antibodies (anti-OX40, anti-GITR, anti-ICOS). Importantly, 2 of the 15 melanoma trials use vaccines as combination partner, specifically neo-antigen peptide vaccine plus Montanide (NCT03929029) and multiple class I peptides and Montanide ISA 51VG (NCT01176474). Another six trials in other tumor indications but melanoma also combine double ICB with vaccines. Four trials combining double ICB plus vaccines have already entered phase II (NCT03190265, NCT03639714, NCT02054520, and NCT03406715).

It is perhaps unexpected that triplet trials using vaccines as partners for toxic double checkpoint blockade (55\% grade 3-4 irAE, 33\% DLT) are that advanced. On the other hand, it is logical, as all the vaccine strategies mentioned above have a very low documented toxicity, and thus qualify as preferred combination partners compared to small molecules, cytokines or agonistic checkpoint molecules. This appears particularly true for DC vaccines. The Tri-Mix DC vaccine developed by K. Thielemans' group was also given in combination with anti-CTL-A4, but again no grade 3 or 4 side 
effects occurred [43], even though Ipilimumab was used at the high dose level of $10 \mathrm{mg} / \mathrm{kg}$, which because of the increased toxicity is avoided nowadays.

The combination of cancer vaccines (including DC vaccines) with chemotherapy has also been explored in the clinic (for a review also of ongoing trials see [129-132]). While significant synergism seems apparent only in few trials, most of them DC studies [133-136], a negative impact has never been reported, as the rules for a successful combination-also derived from animal studies-have been taken into account. These principles are: (1) avoid high-dose chemotherapy, (2) avoid combination after prolonged chemotherapy which results in general immunosuppression, and (3) avoid the concomitant administration of vaccines and cytotoxic drugs but rather administer about 1-2 weeks later. This circumvents the inhibition of activated, proliferating vaccine-induced $\mathrm{T}$ cells, and can dramatically foster T-cell responses by depletion of unwanted myeloid cells [133]. Gemcitabine has been explored in mice and humans in combination DC and other cancer vaccines with promising results [137-141]. Reassuringly, gemcitabine also synergizes with two other types of immune therapy, namely oncolytic virotherapy and ICB [142-144]. Like gemcitabine, fotemustine has already been tested in combination with prolonged vaccination with promising results and no added toxicity [145]. Interestingly, the combination with other immunostimulatory agents, namely IFN alpha + IL-2 and anti-CTL-A4 ICB, was also promising and clinical activity was observed again without evidence for enhanced side effects [146,147].

\section{Conclusions}

Undoubtedly, DC-based cancer vaccines are safe and feasible, and RNA-transfection is emerging as an ideal method for antigen-loading and functional manipulation of the applied cells. While other new cancer treatment regimens involve serious side effects, DC vaccination rarely produces adverse events higher than grade II. This allows a combination treatment in patients with a high tumor burden where DC-based monotherapy yielded only limited clinical results. Additionally, DC vaccines should be further extended to the adjuvant setting, to circumvent the massive immunosuppression exerted by a late stage tumor. Exploration of alternative DC origins and maturation protocols and the functional manipulation of the DCs by transfection with mRNA encoding proteins that trigger activation pathways is a consequent perpetuation to increase their immunogenicity. Currently running and future clinical trials explore these new approaches.

Author Contributions: Conceptualization, J.D. and B.S.-T.; investigation, J.D., N.S., G.S., and B.S.-T.; writing-original draft preparation, J.D.; writing—review and editing, J.D., N.S., G.S., and B.S.-T.; supervision, B.S.-T. All authors have read and agreed to the published version of the manuscript.

Funding: This research was supported by the Deutsche Krebshilfe (German Cancer Aid) and the Hasumi International Research Foundation.

Acknowledgments: We want to thank Mirko Kummer for fruitful discussions. We acknowledge support by the Friedrich-Alexander-Universität Erlangen-Nürnberg (FAU) within the funding program Open Access Publishing.

Conflicts of Interest: The authors declare the following potential conflict of interest: G.S., N.S., and J.D. are named as inventors on a patent on caIKK-RNA-electroporated DCs (WO/2012/055551). The funders had no role in the collection, analyses, or interpretation of data; in the writing of the manuscript, or in the decision to publish the results.

\section{References}

1. Ichim, C.V. Revisiting immunosurveillance and immunostimulation: Implications for cancer Immunother. J. Transl. Med. 2005, 3, 8. [CrossRef]

2. Wiemann, B.; Starnes, C.O. Coley's toxins, tumor necrosis factor and cancer research: A historical perspective. Pharmacol. Ther. 1994, 64, 529-564. [CrossRef]

3. Burnet, F.M. The concept of immunological surveillance. Prog. Exp. Tumor Res. 1970, 13, 1-27. [PubMed]

4. Thomas, L. Discussion. In Cellular and Humoral Aspects of the Hypersensitive States; Lawrence, H.S., Ed.; Hoeber-Harper: New York, NY, USA, 1959. 
5. Dunn, G.P.; Bruce, A.T.; Ikeda, H.; Old, L.J.; Schreiber, R.D. Cancer immunoediting: From immunosurveillance to tumor escape. Nat. Immunol. 2002, 3, 991-998. [CrossRef] [PubMed]

6. Swann, J.B.; Smyth, M.J. Immune surveillance of tumors. J. Clin. Investig. 2007, 117, 1137-1146. [CrossRef] [PubMed]

7. Steinman, R.M.; Cohn, Z.A. Identification of a novel cell type in peripheral lymphoid organs of mice. I. Morphology, quantitation, tissue distribution. J. Exp. Med. 1973, 137, 1142-1162. [CrossRef] [PubMed]

8. Aarntzen, E.H.; Figdor, C.G.; Adema, G.J.; Punt, C.J.; de Vries, I.J. Dendritic cell vaccination and immune monitoring. Cancer Immunol. Immunother. 2008, 57, 1559-1568. [CrossRef] [PubMed]

9. Banchereau, J.; Steinman, R.M. Dendritic cells and the control of immunity. Nature 1998, 392, $245-252$. [CrossRef] [PubMed]

10. Palucka, K.; Banchereau, J. Cancer immunotherapy via dendritic cells. Nat. Rev. Cancer 2012, 12, $265-277$. [CrossRef]

11. Mayordomo, J.I.; Zorina, T.; Storkus, W.J.; Zitvogel, L.; Celluzzi, C.; Falo, L.D.; Melief, C.J.; Ildstad, S.T.; Kast, W.M.; DeLeo, A.B. Bone marrow-derived dendritic cells pulsed with synthetic tumour peptides elicit protective and therapeutic antitumour immunity. Nat. Med. 1995, 1, 1297-1302. [CrossRef]

12. Zitvogel, L.; Mayordomo, J.I.; Tjandrawan, T.; DeLeo, A.B.; Clarke, M.R.; Lotze, M.T.; Storkus, W.J. Therapy of murine tumors with tumor peptide-pulsed dendritic cells: Dependence on T cells, B7 costimulation, and T helper cell 1-associated cytokines. J. Exp. Med. 1996, 183, 87-97. [CrossRef] [PubMed]

13. Hsu, F.J.; Benike, C.; Fagnoni, F.; Liles, T.M.; Czerwinski, D.; Taidi, B.; Engleman, E.G.; Levy, R. Vaccination of patients with B-cell lymphoma using autologous antigen-pulsed dendritic cells. Nat. Med. 1996, 2, $52-58$. [CrossRef] [PubMed]

14. Nestle, F.O.; Banchereau, J.; Hart, D. Dendritic cells: On the move from bench to bedside. Nat. Med. 2001, 7, 761-765. [CrossRef] [PubMed]

15. Bender, A.; Sapp, M.; Schuler, G.; Steinman, R.M.; Bhardwaj, N. Improved methods for the generation of dendritic cells from nonproliferating progenitors in human blood. J. Immunol. Methods 1996, 196, 121-135. [CrossRef]

16. Nestle, F.O.; Alijagic, S.; Gilliet, M.; Sun, Y.; Grabbe, S.; Dummer, R.; Burg, G.; Schadendorf, D. Vaccination of melanoma patients with peptide- or tumor lysate-pulsed dendritic cells. Nat. Med. 1998, 4, 328-332. [CrossRef]

17. Thurner, B.; Haendle, I.; Roder, C.; Dieckmann, D.; Keikavoussi, P.; Jonuleit, H.; Bender, A.; Maczek, C.; Schreiner, D.; von den, D.P.; et al. Vaccination with mage-3A1 peptide-pulsed mature, monocyte-derived dendritic cells expands specific cytotoxic $\mathrm{T}$ cells and induces regression of some metastases in advanced stage IV melanoma. J. Exp. Med. 1999, 190, 1669-1678. [CrossRef]

18. De Vries, I.J.; Bernsen, M.R.; Lesterhuis, W.J.; Scharenborg, N.M.; Strijk, S.P.; Gerritsen, M.J.; Ruiter, D.J.; Figdor, C.G.; Punt, C.J.; Adema, G.J. Immunomonitoring tumor-specific T cells in delayed-type hypersensitivity skin biopsies after dendritic cell vaccination correlates with clinical outcome. J. Clin. Oncol. 2005, 23, 5779-5787. [CrossRef]

19. Banchereau, J.; Palucka, A.K.; Dhodapkar, M.; Burkeholder, S.; Taquet, N.; Rolland, A.; Taquet, S.; Coquery, S.; Wittkowski, K.M.; Bhardwaj, N.; et al. Immune and clinical responses in patients with metastatic melanoma to CD34(+) progenitor-derived dendritic cell vaccine. Cancer Res. 2001, 61, 6451-6458.

20. Beck, B.; Dorfel, D.; Lichtenegger, F.S.; Geiger, C.; Lindner, L.; Merk, M.; Schendel, D.J.; Subklewe, M. Effects of TLR agonists on maturation and function of 3-day dendritic cells from AML patients in complete remission. J. Transl. Med. 2011, 9, 151. [CrossRef]

21. Kalinski, P.; Okada, H. Polarized dendritic cells as cancer vaccines: Directing effector-type T cells to tumors. Semin. Immunol. 2010, 22, 173-182. [CrossRef]

22. Steinman, R.M.; Hemmi, H. Dendritic cells: Translating innate to adaptive immunity. Curr. Top. Microbiol. Immunol. 2006, 311, 17-58. [PubMed]

23. Gallucci, S.; Matzinger, P. Danger signals: SOS to the immune system. Curr. Opin. Immunol. 2001, 13, 114-119. [CrossRef]

24. De Vries, I.J.; Krooshoop, D.J.; Scharenborg, N.M.; Lesterhuis, W.J.; Diepstra, J.H.; Van Muijen, G.N.; Strijk, S.P.; Ruers, T.J.; Boerman, O.C.; Oyen, W.J.; et al. Effective migration of antigen-pulsed dendritic cells to lymph nodes in melanoma patients is determined by their maturation state. Cancer Res. 2003, 63, 12-17. [PubMed] 
25. Dhodapkar, M.V.; Steinman, R.M.; Krasovsky, J.; Munz, C.; Bhardwaj, N. Antigen-specific inhibition of effector T cell function in humans after injection of immature dendritic cells. J. Exp. Med. 2001, 193, 233-238. [CrossRef] [PubMed]

26. Romani, N.; Reider, D.; Heuer, M.; Ebner, S.; Kampgen, E.; Eibl, B.; Niederwieser, D.; Schuler, G. Generation of mature dendritic cells from human blood. An improved method with special regard to clinical applicability. J. Immunol. Methods 1996, 196, 137-151. [CrossRef]

27. Jonuleit, H.; Kuhn, U.; Muller, G.; Steinbrink, K.; Paragnik, L.; Schmitt, E.; Knop, J.; Enk, A.H. Pro-inflammatory cytokines and prostaglandins induce maturation of potent immunostimulatory dendritic cells under fetal calf serum-free conditions. Eur. J. Immunol. 1997, 27, 3135-3142. [CrossRef]

28. Melief, C.J.; van der Burg, S.H. Immunotherapy of established (pre)malignant disease by synthetic long peptide vaccines. Nat. Rev. Cancer 2008, 8, 351-360. [CrossRef]

29. Rains, N.; Cannan, R.J.; Chen, W.; Stubbs, R.S. Development of a dendritic cell (DC)-based vaccine for patients with advanced colorectal cancer. Hepatogastroenterology 2001, 48, 347-351.

30. Nair, S.K.; Morse, M.; Boczkowski, D.; Cumming, R.I.; Vasovic, L.; Gilboa, E.; Lyerly, H.K. Induction of tumor-specific cytotoxic T lymphocytes in cancer patients by autologous tumor RNA-transfected dendritic cells. Ann. Surg. 2002, 235, 540-549. [CrossRef]

31. Su, Z.; Dannull, J.; Heiser, A.; Yancey, D.; Pruitt, S.; Madden, J.; Coleman, D.; Niedzwiecki, D.; Gilboa, E.; Vieweg, J. Immunological and clinical responses in metastatic renal cancer patients vaccinated with tumor RNA-transfected dendritic cells. Cancer Res. 2003, 63, 2127-2133.

32. Caruso, D.A.; Orme, L.M.; Neale, A.M.; Radcliff, F.J.; Amor, G.M.; Maixner, W.; Downie, P.; Hassall, T.E.; Tang, M.L.; Ashley, D.M. Results of a phase 1 study utilizing monocyte-derived dendritic cells pulsed with tumor RNA in children and young adults with brain cancer. Neuro Oncol. 2004, 6, 236-246. [CrossRef] [PubMed]

33. Caruso, D.A.; Orme, L.M.; Amor, G.M.; Neale, A.M.; Radcliff, F.J.; Downie, P.; Tang, M.L.; Ashley, D.M. Results of a Phase I study utilizing monocyte-derived dendritic cells pulsed with tumor RNA in children with Stage 4 neuroblastoma. Cancer 2005, 103, 1280-1291. [CrossRef] [PubMed]

34. Dannull, J.; Su, Z.; Rizzieri, D.; Yang, B.K.; Coleman, D.; Yancey, D.; Zhang, A.; Dahm, P.; Chao, N.; Gilboa, E.; et al. Enhancement of vaccine-mediated antitumor immunity in cancer patients after depletion of regulatory T cells. J. Clin. Investig. 2005, 115, 3623-3633. [CrossRef]

35. Markovic, S.N.; Dietz, A.B.; Greiner, C.W.; Maas, M.L.; Butler, G.W.; Padley, D.J.; Bulur, P.A.; Allred, J.B.; Creagan, E.T.; Ingle, J.N.; et al. Preparing clinical-grade myeloid dendritic cells by electroporation-mediated transfection of in vitro amplified tumor-derived mRNA and safety testing in stage IV malignant melanoma. J. Transl. Med. 2006, 4, 35. [CrossRef] [PubMed]

36. Amin, A.; Dudek, A.Z.; Logan, T.F.; Lance, R.S.; Holzbeierlein, J.M.; Knox, J.J.; Master, V.A.; Pal, S.K.; Miller, W.H., Jr.; Karsh, L.I.; et al. Survival with AGS-003, an autologous dendritic cell-based immunotherapy, in combination with sunitinib in unfavorable risk patients with advanced renal cell carcinoma (RCC): Phase 2 study results. J. Immunother. Cancer 2015, 3, 14. [CrossRef] [PubMed]

37. Kyte, J.A.; Aamdal, S.; Dueland, S.; Saeboe-Larsen, S.; Inderberg, E.M.; Madsbu, U.E.; Skovlund, E.; Gaudernack, G.; Kvalheim, G. Immune response and long-term clinical outcome in advanced melanoma patients vaccinated with tumor-mRNA-transfected dendritic cells. Oncoimmunology 2016, 5, e1232237. [CrossRef]

38. Vik-Mo, E.O.; Nyakas, M.; Mikkelsen, B.V.; Moe, M.C.; Due-Tonnesen, P.; Suso, E.M.; Saeboe-Larssen, S.; Sandberg, C.; Brinchmann, J.E.; Helseth, E.; et al. Therapeutic vaccination against autologous cancer stem cells with mRNA-transfected dendritic cells in patients with glioblastoma. Cancer Immunol. Immunother. 2013, 62, 1499-1509. [CrossRef]

39. Mu, L.J.; Kyte, J.A.; Kvalheim, G.; Aamdal, S.; Dueland, S.; Hauser, M.; Hammerstad, H.; Waehre, H.; Raabe, N.; Gaudernack, G. Immunotherapy with allotumour mRNA-transfected dendritic cells in androgen-resistant prostate cancer patients. Br. J. Cancer 2005, 93, 749-756. [CrossRef]

40. Wilgenhof, S.; Corthals, J.; Van Nuffel, A.M.; Benteyn, D.; Heirman, C.; Bonehill, A.; Thielemans, K.; Neyns, B. Long-term clinical outcome of melanoma patients treated with messenger RNA-electroporated dendritic cell therapy following complete resection of metastases. Cancer Immunol. Immunother. 2015, 64, 381-388. [CrossRef] 
41. Wilgenhof, S.; Van Nuffel, A.M.; Corthals, J.; Heirman, C.; Tuyaerts, S.; Benteyn, D.; De Coninck, A.; Van Riet, I.; Verfaillie, G.; Vandeloo, J.; et al. Therapeutic vaccination with an autologous mRNA electroporated dendritic cell vaccine in patients with advanced melanoma. J. Immunother. 2011, 34, 448-456. [CrossRef]

42. Wilgenhof, S.; Van Nuffel, A.M.; Benteyn, D.; Corthals, J.; Aerts, C.; Heirman, C.; Van Riet, I.; Bonehill, A.; Thielemans, K.; Neyns, B. A phase IB study on intravenous synthetic mRNA electroporated dendritic cell immunotherapy in pretreated advanced melanoma patients. Ann. Oncol 2013, 24, 2686-2693. [CrossRef]

43. Wilgenhof, S.; Corthals, J.; Heirman, C.; van Baren, N.; Lucas, S.; Kvistborg, P.; Thielemans, K.; Neyns, B. Phase II Study of Autologous Monocyte-Derived mRNA Electroporated Dendritic Cells (TriMixDC-MEL) Plus Ipilimumab in Patients with Pretreated Advanced Melanoma. J. Clin. Oncol. 2016, 34, 1330-1338. [CrossRef] [PubMed]

44. Schuurhuis, D.H.; Verdijk, P.; Schreibelt, G.; Aarntzen, E.H.; Scharenborg, N.; de Boer, A.; van de Rakt, M.W.; Kerkhoff, M.; Gerritsen, M.J.; Eijckeler, F.; et al. In situ expression of tumor antigens by messenger RNA-electroporated dendritic cells in lymph nodes of melanoma patients. Cancer Res. 2009, 69, 2927-2934. [CrossRef] [PubMed]

45. Aarntzen, E.H.; Schreibelt, G.; Bol, K.; Lesterhuis, W.J.; Croockewit, A.J.; de Wilt, J.H.; van Rossum, M.M.; Blokx, W.A.; Jacobs, J.F.; Duiveman-de Boer, T.; et al. Vaccination with mRNA-electroporated dendritic cells induces robust tumor antigen-specific CD4+ and CD8+ T cells responses in stage III and IV melanoma patients. Clin. Cancer Res. 2012, 18, 5460-5470. [CrossRef] [PubMed]

46. Bol, K.F.; Figdor, C.G.; Aarntzen, E.H.; Welzen, M.E.; van Rossum, M.M.; Blokx, W.A.; van de Rakt, M.W.; Scharenborg, N.M.; de Boer, A.J.; Pots, J.M.; et al. Intranodal vaccination with mRNA-optimized dendritic cells in metastatic melanoma patients. Oncoimmunology 2015, 4, e1019197. [CrossRef] [PubMed]

47. Bol, K.F.; Aarntzen, E.H.; Pots, J.M.; Olde Nordkamp, M.A.; van de Rakt, M.W.; Scharenborg, N.M.; de Boer, A.J.; van Oorschot, T.G.; Croockewit, S.A.; Blokx, W.A.; et al. Prophylactic vaccines are potent activators of monocyte-derived dendritic cells and drive effective anti-tumor responses in melanoma patients at the cost of toxicity. Cancer Immunol. Immunother. 2016, 65, 327-339. [CrossRef] [PubMed]

48. Bol, K.F.; van den Bosch, T.; Schreibelt, G.; Mensink, H.W.; Keunen, J.E.; Kilic, E.; Japing, W.J.; Geul, K.W.; Westdorp, H.; Boudewijns, S.; et al. Adjuvant Dendritic Cell Vaccination in High-Risk Uveal Melanoma. Ophthalmology 2016, 123, 2265-2267. [CrossRef]

49. Dannull, J.; Haley, N.R.; Archer, G.; Nair, S.; Boczkowski, D.; Harper, M.; De Rosa, N.; Pickett, N.; Mosca, P.J.; Burchette, J.; et al. Melanoma immunotherapy using mature DCs expressing the constitutive proteasome. J. Clin. Investig. 2013, 123, 3135-3145. [CrossRef]

50. Borch, T.H.; Engell-Noerregaard, L.; Zeeberg, I.T.; Ellebaek, E.; Met, O.; Hansen, M.; Andersen, M.H.; thor, S.P.; Svane, I.M. mRNA-transfected dendritic cell vaccine in combination with metronomic cyclophosphamide as treatment for patients with advanced malignant melanoma. Oncoimmunology 2016, 5, e1207842. [CrossRef]

51. Hobo, W.; Strobbe, L.; Maas, F.; Fredrix, H.; Greupink-Draaisma, A.; Esendam, B.; de Witte, T.; Preijers, F.; Levenga, H.; van Rees, B.; et al. Immunogenicity of dendritic cells pulsed with MAGE3, Survivin and B-cell maturation antigen mRNA for vaccination of multiple myeloma patients. Cancer Immunol. Immunother. 2013, 62, 1381-1392. [CrossRef]

52. Wang, D.; Zhang, B.; Gao, H.; Ding, G.; Wu, Q.; Zhang, J.; Liao, L.; Chen, H. Clinical research of genetically modified dendritic cells in combination with cytokine-induced killer cell treatment in advanced renal cancer. BMC Cancer 2014, 14, 251. [CrossRef] [PubMed]

53. Morse, M.A.; Nair, S.K.; Boczkowski, D.; Tyler, D.; Hurwitz, H.I.; Proia, A.; Clay, T.M.; Schlom, J.; Gilboa, E.; Lyerly, H.K. The feasibility and safety of immunotherapy with dendritic cells loaded with CEA mRNA following neoadjuvant chemoradiotherapy and resection of pancreatic cancer. Int. J. Gastrointest. Cancer 2002, 32, 1-6. [CrossRef]

54. Morse, M.A.; Nair, S.K.; Mosca, P.J.; Hobeika, A.C.; Clay, T.M.; Deng, Y.; Boczkowski, D.; Proia, A.; Neidzwiecki, D.; Clavien, P.A.; et al. Immunotherapy with autologous, human dendritic cells transfected with carcinoembryonic antigen mRNA. Cancer Investig. 2003, 21, 341-349. [CrossRef]

55. Lesterhuis, W.J.; de Vries, I.J.; Schreibelt, G.; Schuurhuis, D.H.; Aarntzen, E.H.; de Boer, A.; Scharenborg, N.M.; van de Rakt, M.; Hesselink, E.J.; Figdor, C.G.; et al. Immunogenicity of dendritic cells pulsed with CEA peptide or transfected with CEA mRNA for vaccination of colorectal cancer patients. Anticancer Res. 2010, 30, 5091-5097. [PubMed] 
56. Heiser, A.; Coleman, D.; Dannull, J.; Yancey, D.; Maurice, M.A.; Lallas, C.D.; Dahm, P.; Niedzwiecki, D.; Gilboa, E.; Vieweg, J. Autologous dendritic cells transfected with prostate-specific antigen RNA stimulate CTL responses against metastatic prostate tumors. J. Clin. Investig. 2002, 109, 409-417. [CrossRef] [PubMed]

57. Su, Z.; Dannull, J.; Yang, B.K.; Dahm, P.; Coleman, D.; Yancey, D.; Sichi, S.; Niedzwiecki, D.; Boczkowski, D.; Gilboa, E.; et al. Telomerase mRNA-transfected dendritic cells stimulate antigen-specific CD8+ and CD4+ T cell responses in patients with metastatic prostate cancer. J. Immunol. 2005, 174, 3798-3807. [CrossRef]

58. Khoury, H.J.; Collins, R.H., Jr.; Blum, W.; Stiff, P.S.; Elias, L.; Lebkowski, J.S.; Reddy, A.; Nishimoto, K.P.; Sen, D.; Wirth, E.D., III; et al. Immune responses and long-term disease recurrence status after telomerase-based dendritic cell immunotherapy in patients with acute myeloid leukemia. Cancer 2017, 123, 3061-3072. [CrossRef]

59. Kongsted, P.; Borch, T.H.; Ellebaek, E.; Iversen, T.Z.; Andersen, R.; Met, O.; Hansen, M.; Lindberg, H.; Sengelov, L.; Svane, I.M. Dendritic cell vaccination in combination with docetaxel for patients with metastatic castration-resistant prostate cancer: A randomized phase II study. Cytotherapy 2017, 19, 500-513. [CrossRef]

60. Hernando, J.J.; Park, T.W.; Fischer, H.P.; Zivanovic, O.; Braun, M.; Polcher, M.; Grunn, U.; Leutner, C.; Potzsch, B.; Kuhn, W. Vaccination with dendritic cells transfected with mRNA-encoded folate-receptor-alpha for relapsed metastatic ovarian cancer. Lancet Oncol. 2007, 8, 451-454. [CrossRef]

61. Van Tendeloo, V.F.; Van de Velde, A.; Van Driessche, A.; Cools, N.; Anguille, S.; Ladell, K.; Gostick, E.; Vermeulen, K.; Pieters, K.; Nijs, G.; et al. Induction of complete and molecular remissions in acute myeloid leukemia by Wilms' tumor 1 antigen-targeted dendritic cell vaccination. Proc. Natl. Acad. Sci. USA 2010, 107, 13824-13829. [CrossRef]

62. Coosemans, A.; Vanderstraeten, A.; Tuyaerts, S.; Verschuere, T.; Moerman, P.; Berneman, Z.N.; Vergote, I.; Amant, F.; Van Gool, S.W. Wilms' Tumor Gene 1 (WT1)—Loaded dendritic cell immunotherapy in patients with uterine tumors: A phase I/II clinical trial. Anticancer Res. 2013, 33, 5495-5500. [PubMed]

63. Coosemans, A.; Vanderstraeten, A.; Tuyaerts, S.; Verschuere, T.; Moerman, P.; Berneman, Z.; Vergote, I.; Amant, F.; Van Gool, S.W. Immunological response after WT1 mRNA-loaded dendritic cell immunotherapy in ovarian carcinoma and carcinosarcoma. Anticancer Res. 2013, 33, 3855-3859. [PubMed]

64. Anguille, S.; Van de Velde, A.L.; Smits, E.L.; Van Tendeloo, V.F.; Juliusson, G.; Cools, N.; Nijs, G.; Stein, B.; Lion, E.; Van Driessche, A.; et al. Dendritic cell vaccination as postremission treatment to prevent or delay relapse in acute myeloid leukemia. Blood 2017, 130, 1713-1721. [CrossRef] [PubMed]

65. Shindo, Y.; Hazama, S.; Maeda, Y.; Matsui, H.; Iida, M.; Suzuki, N.; Yoshimura, K.; Ueno, T.; Yoshino, S.; Sakai, K.; et al. Adoptive immunotherapy with MUC1-mRNA transfected dendritic cells and cytotoxic lymphocytes plus gemcitabine for unresectable pancreatic cancer. J. Transl. Med. 2014, 12, 175. [CrossRef] [PubMed]

66. Mitchell, D.A.; Batich, K.A.; Gunn, M.D.; Huang, M.N.; Sanchez-Perez, L.; Nair, S.K.; Congdon, K.L.; Reap, E.A.; Archer, G.E.; Desjardins, A.; et al. Tetanus toxoid and CCL3 improve dendritic cell vaccines in mice and glioblastoma patients. Nature 2015, 519, 366-369. [CrossRef]

67. Maeda, Y.; Yoshimura, K.; Matsui, H.; Shindo, Y.; Tamesa, T.; Tokumitsu, Y.; Hashimoto, N.; Tokuhisa, Y.; Sakamoto, K.; Sakai, K.; et al. Dendritic cells transfected with heat-shock protein 70 messenger RNA for patients with hepatitis $C$ virus-related hepatocellular carcinoma: A phase 1 dose escalation clinical trial. Cancer Immunol. Immunother. 2015, 64, 1047-1056. [CrossRef]

68. Van Craenenbroeck, A.H.; Smits, E.L.; Anguille, S.; Van de Velde, A.; Stein, B.; Braeckman, T.; Van Camp, K.; Nijs, G.; Ieven, M.; Goossens, H.; et al. Induction of cytomegalovirus-specific T cell responses in healthy volunteers and allogeneic stem cell recipients using vaccination with messenger RNA-transfected dendritic cells. Transplantation 2015, 99, 120-127. [CrossRef]

69. Batich, K.A.; Reap, E.A.; Archer, G.E.; Sanchez-Perez, L.; Nair, S.K.; Schmittling, R.J.; Norberg, P.; Xie, W.; Herndon, J.E.; Healy, P.; et al. Long-term Survival in Glioblastoma with Cytomegalovirus pp65-Targeted Vaccination. Clin. Cancer Res. 2017, 23, 1898-1909. [CrossRef]

70. Reap, E.A.; Suryadevara, C.M.; Batich, K.A.; Sanchez-Perez, L.; Archer, G.E.; Schmittling, R.J.; Norberg, P.K.; Herndon, J.E.; Healy, P.; Congdon, K.L.; et al. Dendritic Cells Enhance Polyfunctionality of Adoptively Transferred T Cells That Target Cytomegalovirus in Glioblastoma. Cancer Res. 2018, 78, 256-264. [CrossRef] 
71. Gandhi, R.T.; Kwon, D.S.; Macklin, E.A.; Shopis, J.R.; McLean, A.P.; McBrine, N.; Flynn, T.; Peter, L.; Sbrolla, A.; Kaufmann, D.E.; et al. Immunization of HIV-1-Infected Persons with Autologous Dendritic Cells Transfected WIth mRNA Encoding HIV-1 Gag and Nef: Results of a Randomized, Placebo-Controlled Clinical Trial. J. Acquir. Immune Defic. Syndr. 2016, 71, 246-253. [CrossRef]

72. Routy, J.P.; Boulassel, M.R.; Yassine-Diab, B.; Nicolette, C.; Healey, D.; Jain, R.; Landry, C.; Yegorov, O.; Tcherepanova, I.; Monesmith, T.; et al. Immunologic activity and safety of autologous HIV RNA-electroporated dendritic cells in HIV-1 infected patients receiving antiretroviral therapy. Clin. Immunol. 2010, 134, 140-147. [CrossRef] [PubMed]

73. Jacobson, J.M.; Routy, J.P.; Welles, S.; DeBenedette, M.; Tcherepanova, I.; Angel, J.B.; Asmuth, D.M.; Stein, D.K.; Baril, J.G.; McKellar, M.; et al. Dendritic Cell Immunotherapy for HIV-1 Infection Using Autologous HIV-1 RNA: A Randomized, Double-Blind, Placebo-Controlled Clinical Trial. J. Acquir. Immune Defic. Syndr. 2016, 72, 31-38. [CrossRef] [PubMed]

74. Allard, S.D.; De Keersmaecker, B.; de Goede, A.L.; Verschuren, E.J.; Koetsveld, J.; Reedijk, M.L.; Wylock, C.; De Bel, A.V.; Vandeloo, J.; Pistoor, F.; et al. A phase I/IIa immunotherapy trial of HIV-1-infected patients with Tat, Rev and Nef expressing dendritic cells followed by treatment interruption. Clin. Immunol. 2012, 142, 252-268. [CrossRef]

75. Van Gulck, E.; Vlieghe, E.; Vekemans, M.; Van Tendeloo, V.F.; Van de Velde, A.; Smits, E.; Angille, S.; Coos, N.; Goossens, H.; Mertens, L.; et al. mRNA-based dendritic cell vaccination induces potent antiviral T-cell responses in HIV-1-infected patients. AIDS 2012, 26, F1-F12. [CrossRef] [PubMed]

76. Schuler, G. Dendritic cells in cancer immunotherapy. Eur. J. Immunol. 2010, 40, 2123-2130. [CrossRef]

77. Gilboa, E.; Vieweg, J. Cancer immunotherapy with mRNA-transfected dendritic cells. Immunol. Rev. 2004, 199, 251-263. [CrossRef]

78. Finn, O.J.; Rammensee, H.G. Is It Possible to Develop Cancer Vaccines to Neoantigens, What Are the Major Challenges, and How Can These Be Overcome? Neoantigens: Nothing New in Spite of the Name. Cold Spring Harb. Perspect. Biol. 2018, 10, a028829. [CrossRef]

79. Loffler, M.W.; Kowalewski, D.J.; Backert, L.; Bernhardt, J.; Adam, P.; Schuster, H.; Dengler, F.; Backes, D.; Kopp, H.G.; Beckert, S.; et al. Mapping the HLA Ligandome of Colorectal Cancer Reveals an Imprint of Malignant Cell Transformation. Cancer Res. 2018, 78, 4627-4641. [CrossRef]

80. Newey, A.; Griffiths, B.; Michaux, J.; Pak, H.S.; Stevenson, B.J.; Woolston, A.; Semiannikova, M.; Spain, G.; Barber, L.J.; Matthews, N.; et al. Immunopeptidomics of colorectal cancer organoids reveals a sparse HLA class I neoantigen landscape and no increase in neoantigens with interferon or MEK-inhibitor treatment. J. Immunother. Cancer 2019, 7, 309. [CrossRef]

81. Sahin, U.; Derhovanessian, E.; Miller, M.; Kloke, B.P.; Simon, P.; Lower, M.; Bukur, V.; Tadmor, A.D.; Luxemburger, U.; Schrors, B.; et al. Personalized RNA mutanome vaccines mobilize poly-specific therapeutic immunity against cancer. Nature 2017, 547, 222-226. [CrossRef]

82. Bonehill, A.; Heirman, C.; Tuyaerts, S.; Michiels, A.; Breckpot, K.; Brasseur, F.; Zhang, Y.; Van Der Bruggen, P.; Thielemans, K. Messenger RNA-electroporated dendritic cells presenting MAGE-A3 simultaneously in HLA class I and class II molecules. J. Immunol. 2004, 172, 6649-6657. [CrossRef] [PubMed]

83. Van Lint, S.; Wilgenhof, S.; Heirman, C.; Corthals, J.; Breckpot, K.; Bonehill, A.; Neyns, B.; Thielemans, K. Optimized dendritic cell-based immunotherapy for melanoma: The TriMix-formula. Cancer Immunol. Immunother. 2014, 63, 959-967. [CrossRef] [PubMed]

84. Calderhead, D.M.; DeBenedette, M.A.; Ketteringham, H.; Gamble, A.H.; Horvatinovich, J.M.; Tcherepanova, I.Y.; Nicolette, C.A.; Healey, D.G. Cytokine maturation followed by CD40L mRNA electroporation results in a clinically relevant dendritic cell product capable of inducing a potent proinflammatory CTL response. J. Immunother. 2008, 31, 731-741. [CrossRef] [PubMed]

85. Pfeiffer, I.A.; Hoyer, S.; Gerer, K.F.; Voll, R.E.; Knippertz, I.; Guckel, E.; Schuler, G.; Schaft, N.; Dorrie, J. Triggering of NF-kappaB in cytokine-matured human DCs generates superior DCs for T-cell priming in cancer immunotherapy. Eur. J. Immunol. 2014, 44, 3413-3428. [CrossRef]

86. Bosch, N.C.; Voll, R.E.; Voskens, C.J.; Gross, S.; Seliger, B.; Schuler, G.; Schaft, N.; D+Ârrie, J. NF-kappaB activation triggers NK-cell stimulation by monocyte-derived dendritic cells. Ther. Adv. Med. Oncol. 2019, 11, 1758835919891622. [CrossRef] [PubMed] 
87. Lennerz, V.; Fatho, M.; Gentilini, C.; Frye, R.A.; Lifke, A.; Ferel, D.; Wolfel, C.; Huber, C.; Wolfel, T. The response of autologous $\mathrm{T}$ cells to a human melanoma is dominated by mutated neoantigens. Proc. Natl. Acad. Sci. USA 2005, 102, 16013-16018. [CrossRef] [PubMed]

88. Wood, L.D.; Parsons, D.W.; Jones, S.; Lin, J.; Sjoblom, T.; Leary, R.J.; Shen, D.; Boca, S.M.; Barber, T.; Ptak, J.; et al. The genomic landscapes of human breast and colorectal cancers. Science 2007, 318, 1108-1113. [CrossRef]

89. Pleasance, E.D.; Cheetham, R.K.; Stephens, P.J.; McBride, D.J.; Humphray, S.J.; Greenman, C.D.; Varela, I.; Lin, M.L.; Ordonez, G.R.; Bignell, G.R.; et al. A comprehensive catalogue of somatic mutations from a human cancer genome. Nature 2010, 463, 191-196. [CrossRef]

90. Kowalewski, D.J.; Schuster, H.; Backert, L.; Berlin, C.; Kahn, S.; Kanz, L.; Salih, H.R.; Rammensee, H.G.; Stevanovic, S.; Stickel, J.S. HLA ligandome analysis identifies the underlying specificities of spontaneous antileukemia immune responses in chronic lymphocytic leukemia (CLL). Proc. Natl. Acad. Sci. USA 2015, 112, E166-E175. [CrossRef]

91. Boczkowski, D.; Nair, S.K.; Snyder, D.; Gilboa, E. Dendritic cells pulsed with RNA are potent antigen-presenting cells in vitro and in vivo. J. Exp. Med. 1996, 184, 465-472. [CrossRef]

92. Ashley, D.M.; Faiola, B.; Nair, S.; Hale, L.P.; Bigner, D.D.; Gilboa, E. Bone marrow-generated dendritic cells pulsed with tumor extracts or tumor RNA induce antitumor immunity against central nervous system tumors. J. Exp. Med. 1997, 186, 1177-1182. [CrossRef] [PubMed]

93. Kyte, J.A.; Mu, L.; Aamdal, S.; Kvalheim, G.; Dueland, S.; Hauser, M.; Gullestad, H.P.; Ryder, T.; Lislerud, K.; Hammerstad, H.; et al. Phase I/II trial of melanoma therapy with dendritic cells transfected with autologous tumor-mRNA. Cancer Gene Ther. 2006, 13, 905-918. [CrossRef] [PubMed]

94. Kyte, J.A.; Kvalheim, G.; Lislerud, K.; thor, S.P.; Dueland, S.; Aamdal, S.; Gaudernack, G. T cell responses in melanoma patients after vaccination with tumor-mRNA transfected dendritic cells. Cancer Immunol. Immunother. 2007, 56, 659-675. [CrossRef]

95. Mocellin, S.; Mandruzzato, S.; Bronte, V.; Marincola, F.M. Cancer vaccines: Pessimism in check. Nat. Med. 2004, 10, 1278-1279. [CrossRef] [PubMed]

96. Rosenberg, S.A.; Yang, J.C.; Restifo, N.P. Cancer immunotherapy: Moving beyond current vaccines. Nat. Med. 2004, 10, 909-915. [CrossRef] [PubMed]

97. Timmerman, J.M.; Levy, R. Cancer vaccines: Pessimism in check. Nat. Med. 2004, 10, 1279-1280. [CrossRef] [PubMed]

98. Timmerman, J.M.; Czerwinski, D.K.; Davis, T.A.; Hsu, F.J.; Benike, C.; Hao, Z.M.; Taidi, B.; Rajapaksa, R.; Caspar, C.B.; Okada, C.Y.; et al. Idiotype-pulsed dendritic cell vaccination for B-cell lymphoma: Clinical and immune responses in 35 patients. Blood 2002, 99, 1517-1526. [CrossRef]

99. O'Rourke, M.G.; Johnson, M.; Lanagan, C.; See, J.; Yang, J.; Bell, J.R.; Slater, G.J.; Kerr, B.M.; Crowe, B.; Purdie, D.M.; et al. Durable complete clinical responses in a phase I/II trial using an autologous melanoma cell/dendritic cell vaccine. Cancer Immunol. Immunother. 2003, 52, 387-395. [CrossRef]

100. O’Rourke, M.G.; Johnson, M.K.; Lanagan, C.M.; See, J.L.; O'Connor, L.E.; Slater, G.J.; Thomas, D.; Lopez, J.A.; Martinez, N.R.; Ellem, K.A.; et al. Dendritic cell immunotherapy for stage IV melanoma. Melanoma Res. 2007, 17, 316-322. [CrossRef]

101. Ridgway, D. The first 1000 dendritic cell vaccinees. Cancer Investig. 2003, 21, 873-886. [CrossRef]

102. Engell-Noerregaard, L.; Hansen, T.H.; Andersen, M.H.; thor, S.P.; Svane, I.M. Review of clinical studies on dendritic cell-based vaccination of patients with malignant melanoma: Assessment of correlation between clinical response and vaccine parameters. Cancer Immunol. Immunother. 2009, 58, 1-14. [CrossRef] [PubMed]

103. Kantoff, P.W.; Higano, C.S.; Shore, N.D.; Berger, E.R.; Small, E.J.; Penson, D.F.; Redfern, C.H.; Ferrari, A.C.; Dreicer, R.; Sims, R.B.; et al. Sipuleucel-T immunotherapy for castration-resistant prostate cancer. N. Engl. J. Med. 2010, 363, 411-422. [CrossRef] [PubMed]

104. Wolchok, J.D.; Hoos, A.; O’Day, S.; Weber, J.S.; Hamid, O.; Lebbe, C.; Maio, M.; Binder, M.; Bohnsack, O.; Nichol, G.; et al. Guidelines for the evaluation of immune therapy activity in solid tumors: Immune-related response criteria. Clin. Cancer Res. 2009, 15, 7412-7420. [CrossRef] [PubMed]

105. Hodi, F.S.; O’Day, S.J.; McDermott, D.F.; Weber, R.W.; Sosman, J.A.; Haanen, J.B.; Gonzalez, R.; Robert, C.; Schadendorf, D.; Hassel, J.C.; et al. Improved survival with ipilimumab in patients with metastatic melanoma. N. Engl. J. Med. 2010, 363, 711-723. [CrossRef] [PubMed] 
106. Hellmann, M.D.; Snyder, A. Making It Personal: Neoantigen Vaccines in Metastatic Melanoma. Immunity 2017, 47, 221-223. [CrossRef] [PubMed]

107. Louahed, J.; Gruselle, O. Expression of defined genes identified by pretreatment tumor profiling: Association with clinical responses to the GSK MAGE-A3 immunotherapeutic in metastatic melanoma patients (EORTC 16032-18031). J. Clin. Oncol. 2008, 26, 15. [CrossRef]

108. Gajewski, T.F.; Zha, Y. Association of gene expression profile in metastatic melanoma and survival to a dendritic cell-based vaccine. ASCO Meeting Abstract. J. Clin. Oncol. 2009, 27, 15.

109. Harlin, H.; Meng, Y.; Peterson, A.C.; Zha, Y.; Tretiakova, M.; Slingluff, C.; McKee, M.; Gajewski, T.F. Chemokine expression in melanoma metastases associated with CD8+ T-cell recruitment. Cancer Res. 2009, 69, 3077-3085. [CrossRef]

110. Fong, L.; Brockstedt, D.; Benike, C.; Breen, J.K.; Strang, G.; Ruegg, C.L.; Engleman, E.G. Dendritic cell-based xenoantigen vaccination for prostate cancer immunotherapy. J. Immunol. 2001, 167, 7150-7156. [CrossRef]

111. Geiger, J.D.; Hutchinson, R.J.; Hohenkirk, L.F.; McKenna, E.A.; Yanik, G.A.; Levine, J.E.; Chang, A.E.; Braun, T.M.; Mule, J.J. Vaccination of pediatric solid tumor patients with tumor lysate-pulsed dendritic cells can expand specific T cells and mediate tumor regression. Cancer Res. 2001, 61, 8513-8519.

112. Toungouz, M.; Libin, M.; Bulte, F.; Faid, L.; Lehmann, F.; Duriau, D.; Laporte, M.; Gangji, D.; Bruyns, C.; Lambermont, M.; et al. Transient expansion of peptide-specific lymphocytes producing IFN-gamma after vaccination with dendritic cells pulsed with MAGE peptides in patients with mage-A1/A3-positive tumors. J. Leukoc. Biol. 2001, 69, 937-943. [PubMed]

113. Chang, A.E.; Redman, B.G.; Whitfield, J.R.; Nickoloff, B.J.; Braun, T.M.; Lee, P.P.; Geiger, J.D.; Mule, J.J. A phase I trial of tumor lysate-pulsed dendritic cells in the treatment of advanced cancer. Clin. Cancer Res. 2002, 8, 1021-1032.

114. Vilella, R.; Benitez, D.; Mila, J.; Lozano, M.; Vilana, R.; Pomes, J.; Tomas, X.; Costa, J.; Vilalta, A.; Malvehy, J.; et al. Pilot study of treatment of biochemotherapy-refractory stage IV melanoma patients with autologous dendritic cells pulsed with a heterologous melanoma cell line lysate. Cancer Immunol. Immunother. 2004, 53, 651-658. [CrossRef] [PubMed]

115. Chang, D.H.; Osman, K.; Connolly, J.; Kukreja, A.; Krasovsky, J.; Pack, M.; Hutchinson, A.; Geller, M.; Liu, N.; Annable, R.; et al. Sustained expansion of NKT cells and antigen-specific T cells after injection of alpha-galactosyl-ceramide loaded mature dendritic cells in cancer patients. J. Exp. Med. 2005, 201, 1503-1517. [CrossRef] [PubMed]

116. Mazzolini, G.; Alfaro, C.; Sangro, B.; Feijoo, E.; Ruiz, J.; Benito, A.; Tirapu, I.; Arina, A.; Sola, J.; Herraiz, M.; et al. Intratumoral injection of dendritic cells engineered to secrete interleukin-12 by recombinant adenovirus in patients with metastatic gastrointestinal carcinomas. J. Clin. Oncol. 2005, 23, 999-1010. [CrossRef] [PubMed]

117. Banchereau, J.; Ueno, H.; Dhodapkar, M.; Connolly, J.; Finholt, J.P.; Klechevsky, E.; Blanck, J.P.; Johnston, D.A.; Palucka, A.K.; Fay, J. Immune and clinical outcomes in patients with stage IV melanoma vaccinated with peptide-pulsed dendritic cells derived from CD34+ progenitors and activated with type I interferon. J. Immunother. 2005, 28, 505-516. [CrossRef] [PubMed]

118. Loveland, B.E.; Zhao, A.; White, S.; Gan, H.; Hamilton, K.; Xing, P.X.; Pietersz, G.A.; Apostolopoulos, V.; Vaughan, H.; Karanikas, V.; et al. Mannan-MUC1-pulsed dendritic cell immunotherapy: A phase I trial in patients with adenocarcinoma. Clin. Cancer Res. 2006, 12, 869-877. [CrossRef]

119. Stift, A.; Sachet, M.; Yagubian, R.; Bittermann, C.; Dubsky, P.; Brostjan, C.; Pfragner, R.; Niederle, B.; Jakesz, R.; Gnant, M.; et al. Dendritic cell vaccination in medullary thyroid carcinoma. Clin. Cancer Res. 2004, 10, 2944-2953. [CrossRef]

120. Holtl, L.; Ramoner, R.; Zelle-Rieser, C.; Gander, H.; Putz, T.; Papesh, C.; Nussbaumer, W.; Falkensammer, C.; Bartsch, G.; Thurnher, M. Allogeneic dendritic cell vaccination against metastatic renal cell carcinoma with or without cyclophosphamide. Cancer Immunol. Immunother. 2005, 54, 663-670. [CrossRef]

121. Hodge, J.W.; Ardiani, A.; Farsaci, B.; Kwilas, A.R.; Gameiro, S.R. The tipping point for combination therapy: Cancer vaccines with radiation, chemotherapy, or targeted small molecule inhibitors. Semin. Oncol. 2012, 39, 323-339. [CrossRef] 
122. Zhao, Y.; Qiao, G.; Wang, X.; Song, Y.; Zhou, X.; Jiang, N.; Zhou, L.; Huang, H.; Zhao, J.; Morse, M.A.; et al. Combination of DC/CIK adoptive T cell immunotherapy with chemotherapy in advanced non-small-cell lung cancer (NSCLC) patients: A prospective patients' preference-based study (PPPS). Clin. Transl. Oncol. 2018. [CrossRef] [PubMed]

123. Yanagisawa, R.; Koizumi, T.; Koya, T.; Sano, K.; Koido, S.; Nagai, K.; Kobayashi, M.; Okamoto, M.; Sugiyama, H.; Shimodaira, S. WT1-pulsed Dendritic Cell Vaccine Combined with Chemotherapy for Resected Pancreatic Cancer in a Phase I Study. Anticancer Res. 2018, 38, 2217-2225. [CrossRef] [PubMed]

124. Le, D.T.; Wang-Gillam, A.; Picozzi, V.; Greten, T.F.; Crocenzi, T.; Springett, G.; Morse, M.; Zeh, H.; Cohen, D.; Fine, R.L.; et al. Safety and survival with GVAX pancreas prime and Listeria Monocytogenes-expressing mesothelin (CRS-207) boost vaccines for metastatic pancreatic cancer. J. Clin. Oncol. 2015, 33, 1325-1333. [CrossRef] [PubMed]

125. Massarelli, E.; William, W.; Johnson, F.; Kies, M.; Ferrarotto, R.; Guo, M.; Feng, L.; Lee, J.J.; Tran, H.; Kim, Y.U.; et al. Combining Immune Checkpoint Blockade and Tumor-Specific Vaccine for Patients With Incurable Human Papillomavirus 16-Related Cancer: A Phase 2 Clinical Trial. JAMA Oncol. 2019, 5, 67-73. [CrossRef] [PubMed]

126. Ott, P.A.; Hu, Z.; Keskin, D.B.; Shukla, S.A.; Sun, J.; Bozym, D.J.; Zhang, W.; Luoma, A.; Giobbie-Hurder, A.; Peter, L.; et al. An immunogenic personal neoantigen vaccine for patients with melanoma. Nature 2017, 547, 217-221. [CrossRef]

127. Weber, J.S.; Kudchadkar, R.R.; Yu, B.; Gallenstein, D.; Horak, C.E.; Inzunza, H.D.; Zhao, X.; Martinez, A.J.; Wang, W.; Gibney, G.; et al. Safety, efficacy, and biomarkers of nivolumab with vaccine in ipilimumab-refractory or -naive melanoma. J. Clin. Oncol. 2013, 31, 4311-4318. [CrossRef]

128. Wijn, D.H.; Groeneveld, G.H.; Vollaard, A.M.; Muller, M.; Wallinga, J.; Gelderblom, H.; Smit, E.F. Influenza vaccination in patients with lung cancer receiving anti-programmed death receptor 1 immunotherapy does not induce immune-related adverse events. Eur. J. Cancer 2018, 104, 182-187. [CrossRef]

129. Sprooten, J.; Ceusters, J.; Coosemans, A.; Agostinis, P.; De Vleeschouwer, S.; Zitvogel, L.; Kroemer, G.; Galluzzi, L.; Garg, A.D. Trial watch: Dendritic cell vaccination for cancer immunotherapy. Oncoimmunology 2019, 8, e1638212. [CrossRef]

130. Garg, A.D.; More, S.; Rufo, N.; Mece, O.; Sassano, M.L.; Agostinis, P.; Zitvogel, L.; Kroemer, G.; Galluzzi, L. Trial watch: Immunogenic cell death induction by anticancer chemotherapeutics. Oncoimmunology 2017, 6, e1386829. [CrossRef]

131. van Willigen, W.W.; Bloemendal, M.; Gerritsen, W.R.; Schreibelt, G.; De Vries, I.J.M.; Bol, K.F. Dendritic Cell Cancer Therapy: Vaccinating the Right Patient at the Right Time. Front. Immunol. 2018, 9, 2265. [CrossRef]

132. Belderbos, R.A.; Aerts, J.G.J.V.; Vroman, H. Enhancing Dendritic Cell Therapy in Solid Tumors with Immunomodulating Conventional Treatment. Mol. Ther. Oncolyt. 2019, 13, 67-81. [CrossRef] [PubMed]

133. Welters, M.J.; van der Sluis, T.C.; van Meir, H.; Loof, N.M.; van Ham, V.J.; van Duikeren, S.; Santegoets, S.J.; Arens, R.; de Kam, M.L.; Cohen, A.F.; et al. Vaccination during myeloid cell depletion by cancer chemotherapy fosters robust T cell responses. Sci. Transl. Med. 2016, 8, 334ra52. [CrossRef] [PubMed]

134. Antonia, S.J.; Mirza, N.; Fricke, I.; Chiappori, A.; Thompson, P.; Williams, N.; Bepler, G.; Simon, G.; Janssen, W.; Lee, J.H.; et al. Combination of p53 cancer vaccine with chemotherapy in patients with extensive stage small cell lung cancer. Clin. Cancer Res. 2006, 12, 878-887. [CrossRef] [PubMed]

135. Tanyi, J.L.; Bobisse, S.; Ophir, E.; Tuyaerts, S.; Roberti, A.; Genolet, R.; Baumgartner, P.; Stevenson, B.J.; Iseli, C.; Dangaj, D.; et al. Personalized cancer vaccine effectively mobilizes antitumor T cell immunity in ovarian cancer. Sci. Transl. Med. 2018, 10. [CrossRef]

136. Ogasawara, M.; Miyashita, M.; Ota, S. Vaccination of Urological Cancer Patients With WT1 Peptide-Pulsed Dendritic Cells in Combination With Molecular Targeted Therapy or Conventional Chemotherapy Induces Immunological and Clinical Responses. Ther. Apher. Dial. 2018, 22, 266-277. [CrossRef]

137. Hirooka, Y.; Itoh, A.; Kawashima, H.; Hara, K.; Nonogaki, K.; Kasugai, T.; Ohno, E.; Ishikawa, T.; Matsubara, H.; Ishigami, M.; et al. A combination therapy of gemcitabine with immunotherapy for patients with inoperable locally advanced pancreatic cancer. Pancreas 2009, 38, e69-e74. [CrossRef]

138. Ito, Z.; Kan, S.; Bito, T.; Horiuchi, S.; Akasu, T.; Yoshida, S.; Kajihara, M.; Hokari, A.; Saruta, M.; Yoshida, N.; et al. Predicted Markers of Overall Survival in Pancreatic Cancer Patients Receiving Dendritic Cell Vaccinations Targeting WT1. Oncology 2019, 97, 135-148. [CrossRef] 
139. Bassani-Sternberg, M.; Digklia, A.; Huber, F.; Wagner, D.; Sempoux, C.; Stevenson, B.J.; Thierry, A.C.; Michaux, J.; Pak, H.; Racle, J.; et al. A Phase Ib Study of the Combination of Personalized Autologous Dendritic Cell Vaccine, Aspirin, and Standard of Care Adjuvant Chemotherapy Followed by Nivolumab for Resected Pancreatic Adenocarcinoma-A Proof of Antigen Discovery Feasibility in Three Patients. Front. Immunol. 2019, 10, 1832. [CrossRef]

140. Koido, S.; Homma, S.; Okamoto, M.; Takakura, K.; Mori, M.; Yoshizaki, S.; Tsukinaga, S.; Odahara, S.; Koyama, S.; Imazu, H.; et al. Treatment with chemotherapy and dendritic cells pulsed with multiple Wilms' tumor 1 (WT1)-specific MHC class I/II-restricted epitopes for pancreatic cancer. Clin. Cancer Res. 2014, 20, 4228-4239. [CrossRef]

141. Hardwick, N.R.; Frankel, P.; Ruel, C.; Kilpatrick, J.; Tsai, W.; Kos, F.; Kaltcheva, T.; Leong, L.; Morgan, R.; Chung, V.; et al. p53-Reactive T Cells Are Associated with Clinical Benefit in Patients with Platinum-Resistant Epithelial Ovarian Cancer After Treatment with a p53 Vaccine and Gemcitabine Chemotherapy. Clin. Cancer Res. 2018, 24, 1315-1325. [CrossRef]

142. Gujar, S.A.; Clements, D.; Lee, P.W. Two is better than one: Complementing oncolytic virotherapy with gemcitabine to potentiate antitumor immune responses. Oncoimmunology 2014, 3, e27622. [CrossRef] [PubMed]

143. Tallon de, L.P.; Cecconi, V.; Hiltbrunner, S.; Yagita, H.; Friess, M.; Bode, B.; Opitz, I.; Vrugt, B.; Weder, W.; Stolzmann, P.; et al. Gemcitabine Synergizes with Immune Checkpoint Inhibitors and Overcomes Resistance in a Preclinical Model and Mesothelioma Patients. Clin. Cancer Res. 2018, 24, 6345-6354. [CrossRef] [PubMed]

144. Galsky, M.D.; Wang, H.; Hahn, N.M.; Twardowski, P.; Pal, S.K.; Albany, C.; Fleming, M.T.; Starodub, A.; Hauke, R.J.; Yu, M.; et al. Phase 2 Trial of Gemcitabine, Cisplatin, plus Ipilimumab in Patients with Metastatic Urothelial Cancer and Impact of DNA Damage Response Gene Mutations on Outcomes. Eur. Urol. 2018, 73, 751-759. [CrossRef] [PubMed]

145. Coventry, B.J.; Lilly, C.A.; Hersey, P.; Michele, A.; Bright, R.J. Prolonged repeated vaccine immuno-chemotherapy induces long-term clinical responses and survival for advanced metastatic melanoma. J. Immunother. Cancer 2014, 2, 9. [CrossRef]

146. Terheyden, P.; Becker, J.C.; Kampgen, E.; Brocker, E.B. Sequential interferon-alpha2b, interleukin-2 and fotemustine for patients with metastatic melanoma. Melanoma Res. 2000, 10, 475-482. [CrossRef]

147. Maccalli, C.; Giannarelli, D.; Capocefalo, F.; Pilla, L.; Fonsatti, E.; Di Giacomo, A.M.; Parmiani, G.; Maio, M. Immunological markers and clinical outcome of advanced melanoma patients receiving ipilimumab plus fotemustine in the NIBIT-M1 study. Oncoimmunology 2016, 5, e1071007. [CrossRef] 